Prepared in cooperation with the Poteau Valley Improvement Authority

\title{
Concentrations, Loads, and Yields of Total Phosphorus, Total Nitrogen, and Suspended Sediment and Bacteria Concentrations in the Wister Lake Basin, Oklahoma and Arkansas, 2011-13
}


Front cover:

Background, Wister Lake dam, Oklahoma, 2012. 


\section{Concentrations, Loads, and Yields of Total Phosphorus, Total Nitrogen, and Suspended Sediment and Bacteria Concentrations in the Wister Lake Basin, Oklahoma and Arkansas, 2011-13}

By Stephanie D. Buck

Prepared in cooperation with the Poteau Valley Improvement Authority

Scientific Investigations Report 2014-5170 


\title{
U.S. Department of the Interior SALLY JEWELL, Secretary
}

\section{U.S. Geological Survey \\ Suzette M. Kimball, Acting Director}

\author{
U.S. Geological Survey, Reston, Virginia: 2014
}

For more information on the USGS - the Federal source for science about the Earth, its natural and living resources, natural hazards, and the environment, visit http://www.usgs.gov or call 1-888-ASK-USGS.

For an overview of USGS information products, including maps, imagery, and publications, visit http://www.usgs.gov/pubprod

To order this and other USGS information products, visit http://store.usgs.gov

Any use of trade, firm, or product names is for descriptive purposes only and does not imply endorsement by the U.S. Government.

Although this information product, for the most part, is in the public domain, it also may contain copyrighted materials as noted in the text. Permission to reproduce copyrighted items must be secured from the copyright owner.

Suggested citation:

Buck, S.D., 2014, Concentrations, loads, and yields of total phosphorus, total nitrogen, and suspended sediment and bacteria concentrations in the Wister Lake Basin, Oklahoma and Arkansas, 2011-13: U.S. Geological Survey Scientific Investigations Report 2014-5170, 39 p., http://dx.doi.org/10.3133/sir20145170.

ISSN 2328-031X (print)

ISSN 2328-0328 (online

ISBN 978-1-4113-3852-4 


\section{Acknowledgments}

The author thanks many people for their contributions to the data collection presented in this report. Special thanks go to Waylon Marler for his efforts in collecting water samples in a wide range of conditions. The author also appreciates the helpful peer reviews by Anne Hoos of the U.S. Geological Survey (USGS) Tennessee Water Science Center and Jim Petersen of the USGS Arkansas Water Science Center. The author also appreciates the help of William Andrews, S. Jerrod Smith, and Stan Paxton of the USGS Oklahoma Water Science Center, the board members of the Poteau Valley Improvement Authority, and consultant Steven Patterson of Bio X Design for their suggestions and reviews of this report. 



\section{Contents}

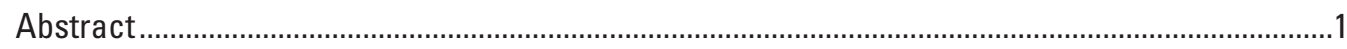

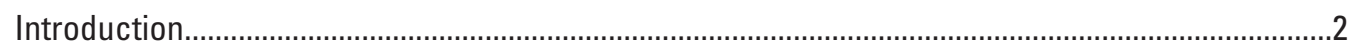

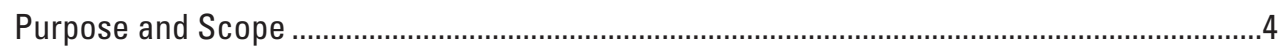

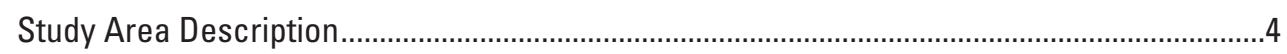

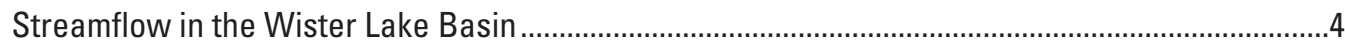

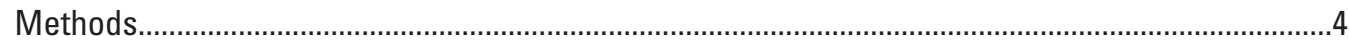

Water-Quality Data Collection and Analysis ..........................................................................

Estimation of Daily Streamflow for Ungaged Water-Quality Stations ........................................

Streamflow Separation .........................................................................................................

Load and Yield Estimation............................................................................................

Assessment of Concentrations, Loads, and Yields of Total Phosphorus,

Total Nitrogen, and Suspended Sediment and Bacteria Concentrations

in the Wister Lake Basin ...........................................................................................10

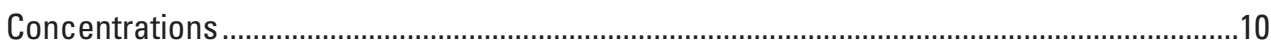

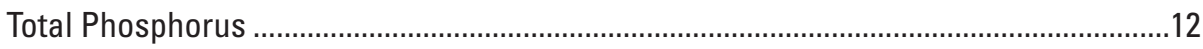

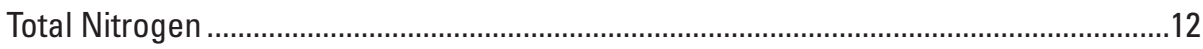

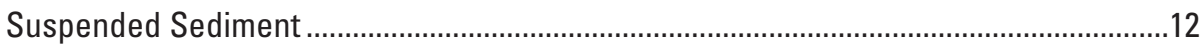

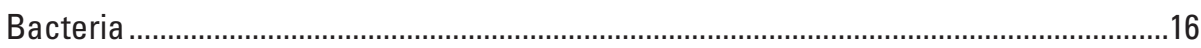

Seasonal Variation of Concentration............................................................................16

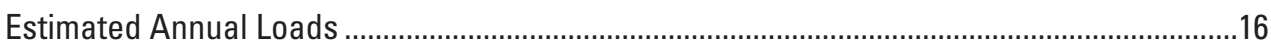

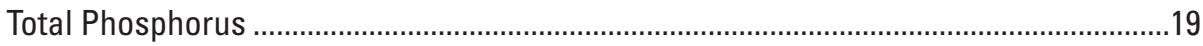

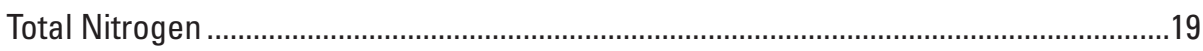

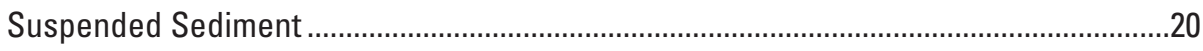

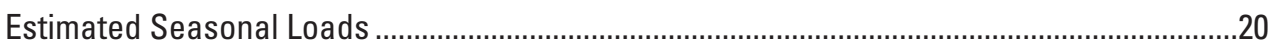

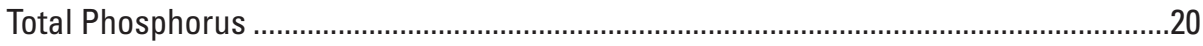

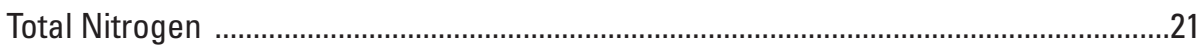

Suspended Sediment ............................................................................................21

Comparison of Estimated Annual Yields Among Stations.....................................................22

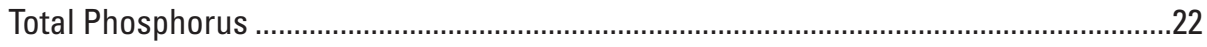

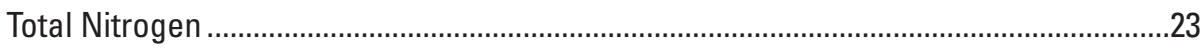

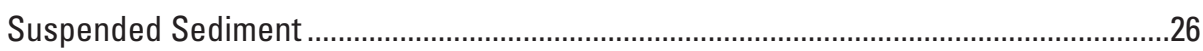

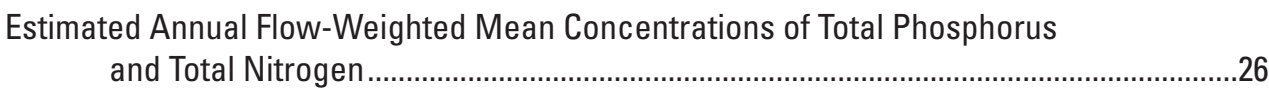

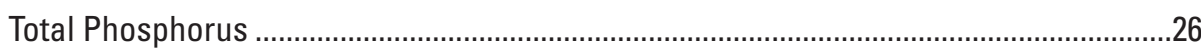

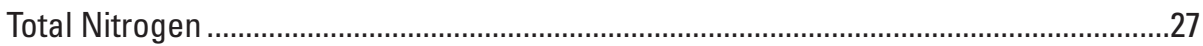

Estimated Annual Total Phosphorus, Total Nitrogen, and Suspended Sediment Loads Discharged into Wister Lake ...............................................................................27

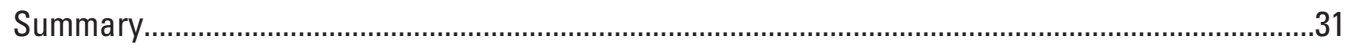

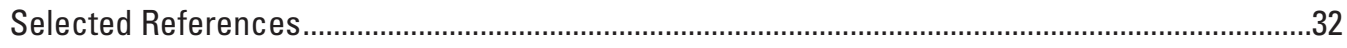

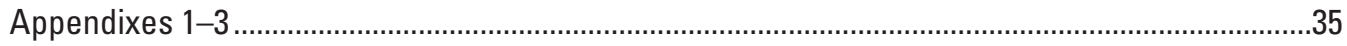




\section{Figures}

1. Map showing the Wister Lake Basin, Oklahoma and Arkansas, with locations of selected real-time streamflow and water-quality data-collection stations and towns with wastewater treatment plants that discharge into streams in the basin, 2011-13.

2. Map showing the Wister Lake Basin, Oklahoma and Arkansas, with 2006 land cover and data-collection stations

3. Map showing the Wister Lake Basin, Oklahoma and Arkansas, and water-quality stations and streamflow-gaging stations that produced data used to compute streamflow for ungaged water-quality stations, 2011-13.

4. Graphs showing streamflow separated into total flow, base flow, and the times and flows at which water-quality samples were collected at the water-quality stations in the Wister Lake Basin, Oklahoma and Arkansas, 2010-13

5. Graphs showing total phosphorus concentrations in water-quality samples collected during base-flow and runoff conditions at the water-quality stations in the Wister Lake Basin, Oklahoma and Arkansas, October 2010 through September 2013.

6. Graphs showing total nitrogen concentrations in water-quality samples collected during base-flow and runoff condtions at the water-quality stations in the Wister Lake Basin, Oklahoma and Arkansas, October 2010 through September 2013.

7. Graphs showing suspended sediment concentrations in water-quality samples collected during base-flow and runoff condtions at the water-quality stations in the Wister Lake Basin, Oklahoma and Arkansas, October 2010 through September 2013.

8. Graphs showing total Escherichia coli bacteria concentrations in water-quality samples collected during base-flow and runoff condtions at the water-quality stations in the Wister Lake Basin, Oklahoma and Arkansas, October 2010 through September 2013

9. Graphs showing Enterococcus sp. bacteria concentrations in water-quality samples collected during base-flow and runoff conditions at the water-quality stations in the Wister Lake Basin, Oklahoma and Arkansas, October 2010 through September 2013 


\section{Tables}

1. Streamflow-gaging station information and streamflow statistics for the water-quality stations sampled in the Wister Lake Basin, Oklahoma and Arkansas, 2011-13

2. Summary statistics of total phosphorus, total nitrogen, suspended sediment, Escherichia coli, and Enterococcus sp. concentrations in water-quality samples collected during base-flow and runoff conditions at water-quality stations in the Wister Lake Basin, Oklahoma and Arkansas, October 2010 through September 2013.

3. Regression models used for estimating total phosphorus, total nitrogen, and suspended sediment loads at water-quality stations sampled in the Wister Lake Basin, Oklahoma and Arkansas, October 2010 to September 2013

4. Estimated annual total phosphorus loads and yields in the Wister Lake Basin, Oklahoma and Arkansas, October 2010 through September 2013

5. Estimated annual total nitrogen loads and yields in the Wister Lake Basin, Oklahoma and Arkansas, October 2010 through September 2013.

6. Estimated annual suspended sediment loads and yields in the Wister Lake Basin, Oklahoma and Arkansas, October 2010 through September 2013

7. Estimates of seasonal total phosphorus loads during base-flow and runoff conditions in the Wister Lake Basin, Oklahoma and Arkansas, October 2010 through September 2013

8. Estimates of seasonal total nitrogen loads during base-flow and runoff conditions in the Wister Lake Basin, Oklahoma and Arkansas, October 2010 through September 2013.

9. Estimates of seasonal suspended sediment loads during base-flow and runoff conditions in the Wister Lake Basin, Oklahoma and Arkansas, October 2010 through September 2013.

10. Estimated annual total phosphorus loads, mean annual streamflows, and flow-weighted mean total phosphorus concentrations at water-quality stations in the Wister Lake Basin, Oklahoma and Arkansas, October 2010 through September 2013.

11. Estimated annual total nitrogen loads, mean annual streamflows, and flow-weighted mean total nitrogen concentrations at water-quality stations in the Wister Lake Basin, Oklahoma and Arkansas, October 2010 through September 2013.

12. Estimated annual total phosphorus loads discharged to Wister Lake, Oklahoma and Arkansas, October 2010 through September 2013.

13. Estimated annual total nitrogen loads discharged to Wister Lake, Oklahoma and Arkansas, October 2010 through September 2013

14. Estimated annual total suspended sediment loads discharged to Wister Lake, Oklahoma and Arkansas, October 2010 through September 2013 


\section{Conversion Factors}

Inch/Pound to SI

\begin{tabular}{|c|c|c|}
\hline Multiply & By & To obtain \\
\hline \multicolumn{3}{|c|}{ Length } \\
\hline foot $(\mathrm{ft})$ & 0.3048 & meter $(\mathrm{m})$ \\
\hline mile (mi) & 1.609 & kilometer $(\mathrm{km})$ \\
\hline mile, nautical (nmi) & 1.852 & kilometer $(\mathrm{km})$ \\
\hline \multicolumn{3}{|c|}{ Area } \\
\hline acre & 4,047 & square meter $\left(\mathrm{m}^{2}\right)$ \\
\hline acre & 0.4047 & hectare (ha) \\
\hline square mile $\left(\mathrm{mi}^{2}\right)$ & 259.0 & hectare (ha) \\
\hline square mile $\left(\mathrm{mi}^{2}\right)$ & 2.590 & square kilometer $\left(\mathrm{km}^{2}\right)$ \\
\hline \multicolumn{3}{|c|}{ Volume } \\
\hline acre-foot (acre-ft) & 1,233 & cubic meter $\left(\mathrm{m}^{3}\right)$ \\
\hline \multicolumn{3}{|c|}{ Flow rate } \\
\hline acre-foot per day (acre-ft/d) & 0.01427 & cubic meter per second $\left(\mathrm{m}^{3} / \mathrm{s}\right)$ \\
\hline acre-foot per year (acre-ft/yr) & 1,233 & cubic meter per year $\left(\mathrm{m}^{3} / \mathrm{yr}\right)$ \\
\hline $\begin{array}{l}\text { cubic foot per second per square } \\
\text { mile }\left[\left(\mathrm{ft}^{3} / \mathrm{s}\right) / \mathrm{mi}^{2}\right]\end{array}$ & 0.01093 & $\begin{array}{l}\text { cubic meter per second per square } \\
\text { kilometer }\left[\left(\mathrm{m}^{3} / \mathrm{s}\right) / \mathrm{km}^{2}\right]\end{array}$ \\
\hline cubic foot per day $\left(\mathrm{ft}^{3} / \mathrm{d}\right)$ & 0.02832 & cubic meter per day $\left(\mathrm{m}^{3} / \mathrm{d}\right)$ \\
\hline \multicolumn{3}{|c|}{ Mass } \\
\hline ton, long $(2,240 \mathrm{lb})$ & 1.016 & megagram (Mg) \\
\hline $\begin{array}{l}\text { ton per day per square mile } \\
{\left[(\text { ton } / \mathrm{d}) / \mathrm{mi}^{2}\right]}\end{array}$ & 0.3503 & $\begin{array}{l}\text { megagram per day per square } \\
\text { kilometer }\left[(\mathrm{Mg} / \mathrm{d}) / \mathrm{km}^{2}\right]\end{array}$ \\
\hline ton per year (ton/yr) & 0.9072 & megagram per year (Mg/yr) \\
\hline ton per year (ton/yr) & 0.9072 & metric ton per year \\
\hline
\end{tabular}

Temperature in degrees Celsius $\left({ }^{\circ} \mathrm{C}\right)$ may be converted to degrees Fahrenheit $\left({ }^{\circ} \mathrm{F}\right)$ as follows:

${ }^{\circ} \mathrm{F}=\left(1.8 \mathrm{x}^{\circ} \mathrm{C}\right)+32$

Temperature in degrees Fahrenheit $\left({ }^{\circ} \mathrm{F}\right)$ may be converted to degrees Celsius $\left({ }^{\circ} \mathrm{C}\right)$ as follows:

${ }^{\circ} \mathrm{C}=\left({ }^{\circ} \mathrm{F}-32\right) / 1.8$

Vertical coordinate information is referenced to the North American Vertical Datum of 1988 (NAVD 88). The NAVD 88 replaced the National Geodetic Vertical Datum of 1929 (NGVD 29), previously known as the Sea Level Datum of 1929.

Horizontal coordinate information is referenced to the North American Datum of 1983 (NAD 83).

Altitude, as used in this report, refers to distance above the vertical datum.

Concentrations of chemical constituents in water are given either in milligrams per liter (mg/L) or micrograms per liter ( $\mu \mathrm{g} / \mathrm{L})$. 


\title{
Concentrations, Loads, and Yields of Total Phosphorus, Total Nitrogen, and Suspended Sediment and Bacteria Concentrations in the Wister Lake Basin, Oklahoma and Arkansas, 2011-13
}

\author{
By Stephanie D. Buck
}

\section{Abstract}

The Poteau Valley Improvement Authority uses Wister Lake in southeastern Oklahoma as a public water supply. Total phosphorus, total nitrogen, and suspended sediments from agricultural runoff and discharges from wastewater treatment plants and other sources have degraded water quality in the lake. As lake-water quality has degraded, water-treatment cost, chemical usage, and sludge production have increased for the Poteau Valley Improvement Authority.

The U.S. Geological Survey (USGS), in cooperation with the Poteau Valley Improvement Authority, investigated and summarized concentrations of total phosphorus, total nitrogen, suspended sediment, and bacteria (Escherichia coli and Enterococcus sp.) in surface water flowing to Wister Lake. Estimates of total phosphorus, total nitrogen, and suspended sediment loads, yields, and flow-weighted mean concentrations of total phosphorus and total nitrogen concentrations were made for the Wister Lake Basin for a 3-year period from October 2010 through September 2013. Data from water samples collected at fixed time increments during base-flow conditions and during runoff conditions at the Poteau River at Loving, Okla. (USGS station 07247015), the Poteau River near Heavener, Okla. (USGS station 07247350), and the Fourche Maline near Leflore, Okla. (USGS station 07247650) water-quality stations were used to evaluate water quality over the range of streamflows in the basin. These data also were collected to estimate annual constituent loads and yields by using regression models.

At the Poteau River stations, total phosphorus, total nitrogen, and suspended sediment concentrations in surfacewater samples were significantly larger in samples collected during runoff conditions than in samples collected during base-flow conditions. At the Fourche Maline station, in contrast, concentrations of these constituents in water samples collected during runoff conditions were not significantly larger than concentrations during base-flow conditions. Flowweighted mean total phosphorus concentrations at all three stations from 2011 to 2013 were several times larger than the Oklahoma State Standard for Scenic Rivers (0.037 milligrams per liter $[\mathrm{mg} / \mathrm{L}]$ ), with the largest flow-weighted phosphorus concentrations typically being measured at the Poteau River at Loving, Okla., station. Flow-weighted mean total nitrogen concentrations did not vary substantially between the Poteau River stations and the Fourche Maline near Leflore, Okla., station. At all of the sampled water-quality stations, bacteria (Escherichia coli and Enterococcus sp.) concentrations were substantially larger in water samples collected during runoff conditions than in water samples collected during base-flow conditions from 2011 to 2013.

Estimated annual loads of total phosphorus, total nitrogen, and suspended sediment in the Poteau River stations during runoff conditions ranged from 82 to 98 percent of the total annual loads of those constituents. Estimated annual loads of total phosphorus, total nitrogen, and suspended sediment in the Fourche Maline during runoff conditions ranged from 86 to nearly 100 percent of the total annual loads.

Estimated seasonal total phosphorus loads generally were smallest during base-flow and runoff conditions in autumn. Estimated seasonal total phosphorus loads during base-flow conditions tended to be largest in winter and during runoff conditions tended to be largest in the spring. Estimated seasonal total nitrogen loads tended to be smallest in autumn during base-flow and runoff conditions and largest in winter during runoff conditions. Estimated seasonal suspended sediment loads tended to be smallest during baseflow conditions in the summer and smallest during runoff conditions in the autumn. The largest estimated seasonal suspended sediment loads during runoff conditions typically were in the spring.

The estimated mean annual total phosphorus yield was largest at the Poteau River at Loving, Okla., water-quality station. The estimated mean annual total phosphorus yield was largest during base flow at the Poteau River at Loving, Okla., water-quality station and at both of the Poteau River waterquality stations during runoff conditions. The estimated mean annual total nitrogen yields were largest at the Poteau River 
water-quality stations. Estimated mean annual total nitrogen yields were largest during base-flow and runoff conditions at the Poteau River at Loving, Okla., water-quality station. The estimated mean annual suspended sediment yield was largest at the Poteau River near Heavener, Okla., water-quality station during base-flow and runoff conditions.

Flow-weighted mean concentrations indicated that total phosphorus inputs from the Poteau River Basin in the Wister Lake Basin were larger than from the Fourche Maline Basin. Flow-weighted mean concentrations of total nitrogen did not vary spatially in a consistent manner.

The Poteau River and the Fourche Maline contributed estimated annual total phosphorus loads of 137 to 278 tons per year (tons/yr) to Wister Lake. Between 89 and 95 percent of the annual total phosphorus loads were transported to Wister Lake during runoff conditions. The Poteau River and the Fourche Maline contributed estimated annual total nitrogen loads of 657 to 1,294 tons/yr, with 86 to 94 percent of the annual total nitrogen loads being transported to Wister Lake during runoff conditions. The Poteau River and the Fourche Maline contributed estimated annual total suspended sediment loads of 110,919 to 234,637 tons/yr, with 94 to 99 percent of the annual suspended sediment loads being transported to Wister Lake during runoff conditions. Most of the total phosphorus and suspended sediment were delivered to Wister Lake during runoff conditions in the spring. The majority of the total nitrogen was delivered to Wister Lake during runoff conditions in winter.

\section{Introduction}

Wister Lake is the sole source of public water supplies for many residents and provides the water supply for all businesses in Le Flore County, Oklahoma (fig. 1) (Poteau Valley Improvement Authority, 2009). Wister Lake was constructed in 1949, and the Poteau Valley Improvement Authority (PVIA) began using the lake as a drinking water supply in 1969 (Poteau Valley Improvement Authority, 2009). Estimated total daily water use for Le Flore County in 2005 was about 20 million gallons per day, with most of the withdrawal of water in that county being for public supply (Tortorelli, 2009). Relatively large concentrations of total phosphorus, total nitrogen, and suspended sediment in the lake have caused it to become very turbid and eutrophic (containing increased amounts of algae and other aquatic plants caused by elevated concentrations of total phosphorus and total nitrogen) since a U.S. Environmental Protection Agency (EPA) survey was conducted in 1974 (Hession and others, 1996; Oklahoma Department of Environmental Quality, 2008). Wister Lake is cited in the Oklahoma Department of Environmental Quality (ODEQ) 2008 Section 303(d) of the Clean Water Act list of impaired water bodies because of relatively large concentrations of total phosphorus, total nitrogen, and suspended sediment. Such a listing requires that a Total
Maximum Daily Load (TMDL) estimate be prepared for the lake (Oklahoma Department of Environmental Quality, 2008; Poteau Valley Improvement Authority, 2009). A TMDL is a calculation of the maximum amount of a pollutant that a water body can receive and still meet water-quality standards (U.S. Environmental Protection Agency, 2013).

The mission of the PVIA is to produce and distribute potable water supplies to more than 40,000 customers through 16 member municipalities and rural water districts (Poteau Valley Improvement Authority, 2009; U.S. Census Bureau, 2012). The PVIA service region includes about 80 percent of Le Flore County, Okla. Deterioration of water quality in the lake has been caused by inflows of total phosphorus, total nitrogen, and suspended sediment from point and nonpoint sources surrounding and upstream of the lake (Oklahoma Department of Environmental Quality, 2008). Nonpoint sources can include runoff from agricultural areas, forests, dirt roads, and construction sites. Additionally, discharges from point sources such as wastewater-treatment (WWT) facilities and improperly functioning onsite wastewater treatment systems also may contribute total phosphorus and total nitrogen to the lake (Busteed and others, 2009; Poteau Valley Improvement Authority, 2009; U.S. Geological Survey, 1999). Deteriorating water quality in this lake has increased watertreatment costs, the amounts of treatment chemicals used, and production of sludge from water-treatment processes (Poteau Valley Improvement Authority, 2009).

Elevated concentrations of total phosphorus, total nitrogen, suspended sediment, and bacteria are the most common sources of impairment of surface-water quality in the United States (U.S. Environmental Protection Agency, 2009). Determination of a TMDL requires estimation of the total load of a substance in a lake and contributions of those substances to a lake from nonpoint and point sources. To account for nonpoint sources contributing to the lake, water samples need to be collected during runoff conditions (Petersen and others, 2005). Other studies in basins in Oklahoma with similar land uses have shown that about 75 to 95 percent of total phosphorus and total nitrogen loads flow downstream during runoff conditions (Tortorelli, 2008; Andrews and others, 2009; Esralew and others, 2011). Fecal-indicator bacteria such as Escherichia coli and Enterococcus sp. also can seep in groundwater or be washed by runoff to streams from nonpoint and point sources. Mott and Steele (1991) reported that at the Buffalo River Basin in Arkansas, a single rain event can transport larger numbers of such bacteria from pastures into that river compared to base-flow conditions. Busteed and others (2009) described a study to identify critical source areas (CSAs) that contribute disproportionate pollutant loads to the lake, but the model used for that study was calibrated on the basis of nutrient concentrations from water samples that typically were collected during base-flow conditions (streamflow that occurs during relatively dry periods that is composed largely of groundwater seepage and treated wastewater from point-source discharges). Underrepresentation of samples collected during runoff 


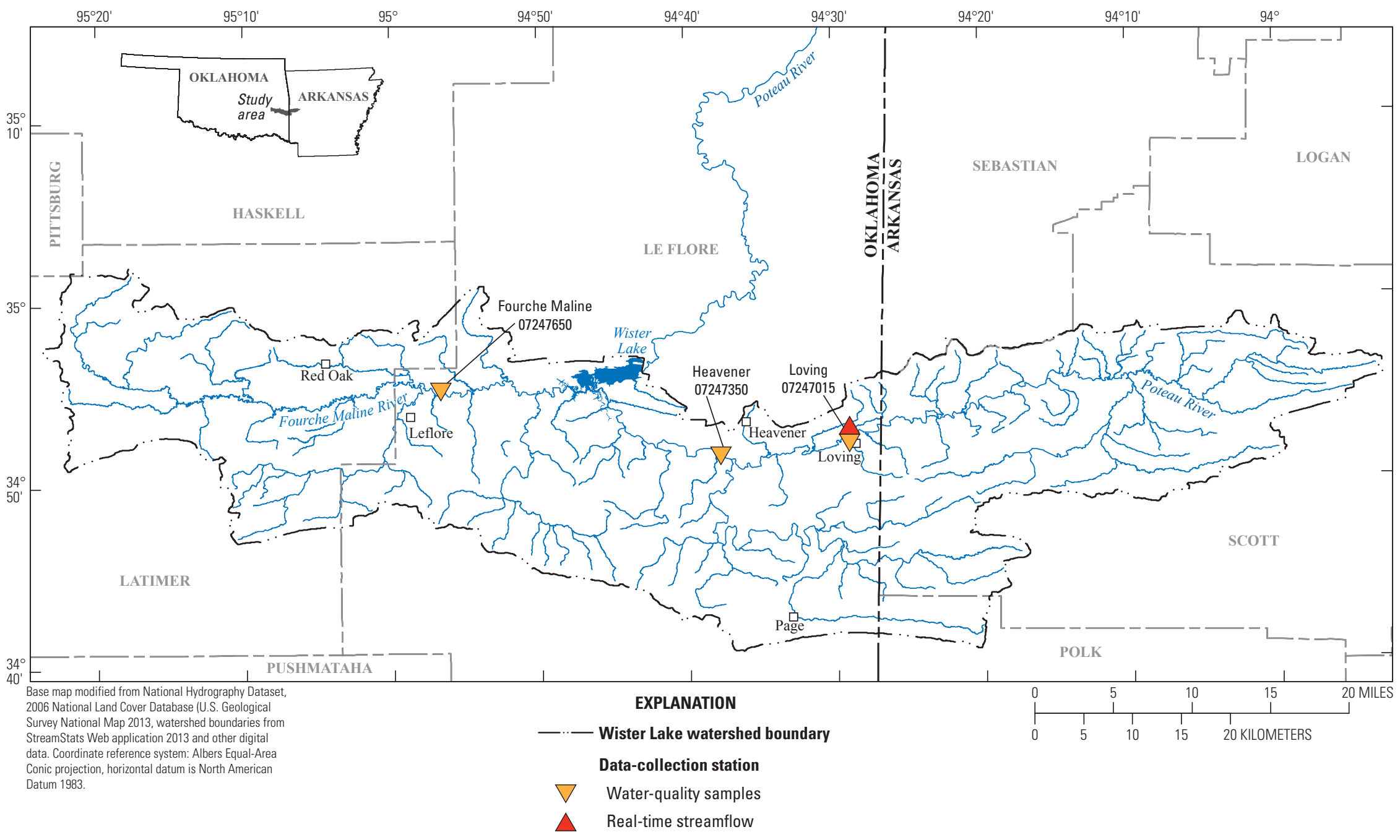

Figure 1. The Wister Lake Basin, Oklahoma and Arkansas, with locations of selected real-time streamflow and water-quality data-collection stations and towns with wastewater treatment plants that discharge into streams in the basin, 2011-13. 
(also known as high-flow) conditions reduces the ability to reliably estimate concentrations and loads of constituents flowing down a stream during those conditions. Water-quality sampling conducted in this basin prior to the study described in this report did not include collection of notable numbers of surface-water samples at runoff conditions or analysis of suspended sediment and bacteria concentrations in water samples (Busteed and others, 2009).

\section{Purpose and Scope}

The purpose of this report is to describe concentrations, loads, and yields of total phosphorus, total nitrogen, and suspended sediment and concentrations of bacteria in the two principal tributaries of Wister Lake. This report provides annual estimates of total phosphorus, total nitrogen, and suspended sediment loads, yields, and flow-weighted mean (FWM) concentrations in the Poteau River and Fourche Maline from October 2010 through September 2013 (also known as water years 2011-13; a water year is the 12-month period October 1 through September 30 designated by the calendar year in which it ends). Load estimates by season and flow (base-flow versus runoff components) for the 3-year period also are presented for these constituents.

Total phosphorus, total nitrogen, suspended sediment, and bacteria (Escherichia coli and Enterococcus sp.) concentrations were compared for water samples collected by the U.S. Geological Survey (USGS) at three stations in the Wister Lake Basin. Those concentrations also were compared to Oklahoma State Standards for Scenic Rivers (State of Oklahoma, 2006) to flow-weighted concentrations measured mostly at undeveloped basins of the United States (Clark and others, 2000) and to Oklahoma State Standards for Primary Body Contact Recreation (State of Oklahoma, 2006). This report provides information needed to increase understanding of hydrology and water quality in the Wister Lake Basin and provides hydrologic data and interpretations that can be used to implement and enhance land-use and water-management policies for the Wister Lake Basin.

\section{Study Area Description}

Wister Lake in southeastern Oklahoma (fig. 1) receives inflows of water primarily from the Poteau River to the east and the Fourche Maline to the west. The Wister Lake Basin consists of approximately 930 square miles $\left(\mathrm{mi}^{2}\right)$ in southeastern Oklahoma and southwestern Arkansas. Wister Lake was constructed in 1949 by the U.S. Army Corps of Engineers (USACE) to provide flood control, water supply, flow regulation, and conservation (Poteau Valley Improvement Authority, 2009). The recreation opportunities Wister Lake provides are economically important for the surrounding area (Hession and others, 1996).

The study area surrounding Wister Lake Basin is about 65 percent forest, 34 percent pasture and cropland, and
1 percent urban (fig. 2; Multi-Resolution Land Characteristics Consortium, 2013). There were 1,428 cattle farms and 316 poultry farms in this basin as of 2007 (U.S. Department of Agriculture, 2007). There are 2 municipal WWT facilities in Heavener that discharge into the Poteau River and 1 WWT facility that discharges into the Fourche Maline at Red Oak (fig.1). Streams receiving discharges of effluent from WWT facilities can have relatively large phosphorus and nitrogen concentrations during base-flow conditions in the Poteau River, whereas bacteria concentrations typically have been largest in nonpoint source runoff in this region (Petersen and others, 2005).

\section{Streamflow in the Wister Lake Basin}

Streamflow in the Wister Lake Basin varied considerably during water years 2011-13 (table 1). The Poteau River, the primary stream that discharges to Wister Lake from the east, contributed the majority of the water flowing into the lake, with streamflow at particular sites increasing with upstream drainage area (table 1). Maximum daily streamflows for the study period were recorded in November 2011 at the Poteau River at Loving., Okla., water-quality station; in May 2013 at the Poteau River near Heavener, Okla., water-quality station; and in April 2011 at the Fourche Maline near Leflore, Okla., water-quality station (see Estimation of Daily Streamflow for Ungaged Water-Quality Stations section of this report) (fig. 3). Minimum recorded streamflows were zero flow, which were recorded at each of these three stations periodically during the 2011 and 2012 water years. At these stations, the largest monthly streamflows generally were measured from March to June, whereas the smallest monthly streamflows generally were measured from July through October (fig. 4).

\section{Methods}

Methods used for water-quality data collection and analysis, estimation of streamflow at ungaged stations, streamflow separation into base flow and runoff, statistical tests used to compare groups of data, and computation of statistics of phosphorus and nitrogen concentrations in the Wister Lake Basin from 2011 to 2013 are described in this section. Regression methods used to estimate phosphorus, nitrogen, and sediment loads and yields at selected stations in this basin also are described.

\section{Water-Quality Data Collection and Analysis}

Water-quality data were collected at three stations: the USGS streamflow-gaging station Poteau River at Loving, Okla., (USGS station 07247015) and two ungaged waterquality stations, Poteau River near Heavener, Okla., (USGS 


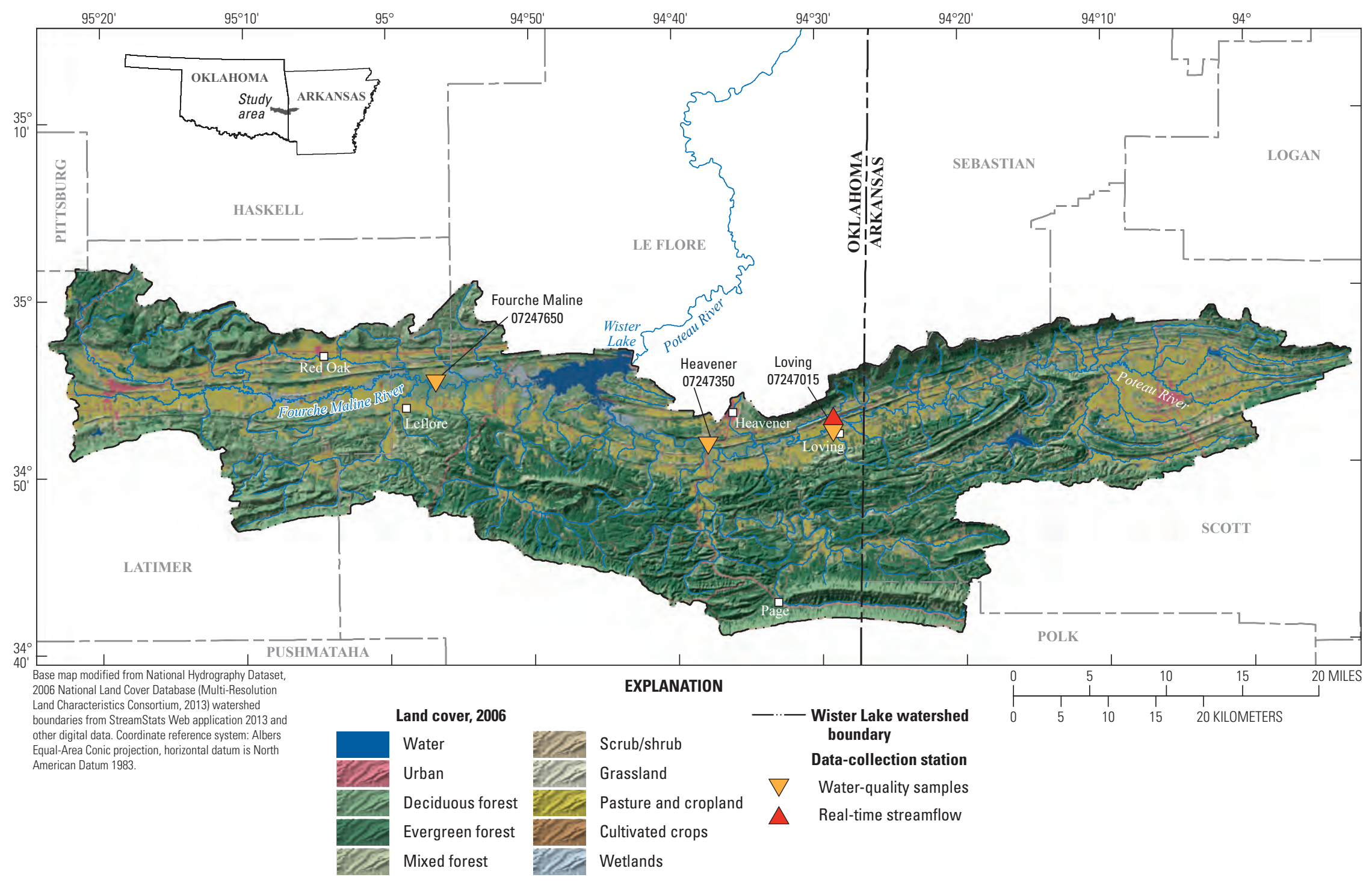

Figure 2. The Wister Lake Basin, Oklahoma and Arkansas, with 2006 land cover and data-collection stations. 
Table 1. Streamflow-gaging station information and streamflow statistics for the water-quality stations sampled in the Wister Lake Basin, Oklahoma and Arkansas, 2011-13.

[ddmmss, degrees, minutes, seconds; $\mathrm{mi}^{2}$, square mile; $\mathrm{ft}^{3} / \mathrm{s}$, cubic feet per second]

\begin{tabular}{|c|c|c|c|c|c|c|c|c|}
\hline \multirow[t]{2}{*}{$\begin{array}{l}\text { U.S. Geological Survey } \\
\text { station name (number) }\end{array}$} & \multirow[t]{2}{*}{$\begin{array}{l}\text { Latitude } \\
\text { (ddmmss) }\end{array}$} & \multirow[t]{2}{*}{$\begin{array}{l}\text { Longitude } \\
\text { (ddmmss) }\end{array}$} & \multirow{2}{*}{$\begin{array}{l}\text { Upstream } \\
\text { drainage } \\
\text { area } \\
\left(\mathrm{mi}^{2}\right)\end{array}$} & \multicolumn{3}{|c|}{$\begin{array}{l}\text { Mean annual } \\
\text { streamflow } \\
\left(\mathrm{ft}^{3} / \mathrm{s}\right)\end{array}$} & \multicolumn{2}{|c|}{$\begin{array}{c}\text { Minimum and maximum daily } \\
\text { mean streamflow for study period Octo- } \\
\text { ber } 2010-\text { September } 2013 \\
\left(\mathrm{ft}^{3} / \mathrm{s}\right)\end{array}$} \\
\hline & & & & 2011 & 2012 & 2013 & $\begin{array}{l}\text { Minimum } \\
\text { (date) }\end{array}$ & $\begin{array}{l}\text { Maximum } \\
\text { (date) }\end{array}$ \\
\hline $\begin{array}{l}\text { Poteau River at } \\
\text { Loving, Okla. } \\
(07247015)\end{array}$ & 345247 & 942902 & 268 & 192.6 & 405.8 & 379.9 & $\begin{array}{l}5 \text { zero-flow days in } \\
\text { 2011, } 11 \text { zero-flow } \\
\text { days in } 2012\end{array}$ & $\begin{array}{c}17,900 \\
(11 / 22 / 2011)\end{array}$ \\
\hline $\begin{array}{l}\text { Poteau River near } \\
\text { Heavener, Okla. } \\
(07247350)\end{array}$ & 345130 & 943745 & 515 & 415.0 & 846.7 & 911.0 & $\begin{array}{l}5 \text { zero-flow days in } \\
2011,6 \text { zero-flow } \\
\text { days } 2012\end{array}$ & $\begin{array}{c}64,819 \\
(5 / 31 / 2013)\end{array}$ \\
\hline
\end{tabular}

station 07247350) and Fourche Maline near Leflore, Okla., (USGS station 07247650), all of which are referred to in the remainder of this text as "stations" (fig. 1, table 1). The station on the Poteau River at Loving, Okla., was operated, and streamflows were measured according to methods described by Rantz and others (1982). At the ungaged stations on the Poteau River near Heavener, Okla., and the Fourche Maline near Leflore, Okla., streamflow measurements were made on the same dates as water-qualitysample collection in accordance with methods described by Rantz and others (1982).

Surface-water-quality data used for determining concentrations and estimating loads should be collected at a range of flow conditions (from low to high) in approximately equal numbers in all seasons (Tortorelli, 2008). Thirtysix water samples were collected from October 2010 to September 2013 at each of these three stations. Those samples were collected over wide ranges of streamflows and seasonal conditions (fig. 4). During each of the 3 years at each of these stations, 6 fixed-frequency water-quality samples per year were collected during low- to medianflow conditions, and 6 water-quality samples were sampled during higher flow (runoff) conditions. All of those samples were collected by using isokinetic equal-width incremental methods (Edwards and Glysson, 1999) which are designed to weight the amount of water collected across the width of a stream channel to include greater amounts from the faster flowing parts of stream cross sections. The water samples were sent to the USGS National Water-Quality Laboratory in Denver, Colorado, for analysis of concentrations of total phosphorus and total nitrogen. Water samples to be analyzed for suspended sediment concentration were sent to the USGS Iowa Sediment Laboratory in Iowa City, Iowa, at the beginning of water year 2011 and the USGS Missouri Sediment Laboratory in Rolla, Missouri, for the remainder of the study period. Bacteria concentrations were analyzed by USGS Tulsa (Okla.) Field Office personnel by using IDEXX ${ }^{\circledR}$ Colilert ${ }^{\circledR}$ for Escherichia coli concentrations and IDEXX ${ }^{\circledR}$ Enterolert ${ }^{\circledR}$ for Enterococcus sp. concentrations, by following methods described in U.S. Geological Survey (2006), Harwell and Mobley (2009), and IDEXX Laboratories (2009).

U.S. Geological Survey protocols and procedures were followed for quality assurance (QA), as described in U.S. Geological Survey (2006). Collection of quality-control (QC) samples is a mandated USGS practice for water-quality field studies (U.S. Geological Survey, 2006) and is an important component of the quality assurance of this project. The goal of quality-assurance sampling is to identify, quantify, and document bias and variability in data that result from the collection, processing, shipping, and handling of samples. Field blanks and field sequential replicates were collected by the USGS at rates of 3 to 7 percent of the number of environmental samples collected.

Three blank samples were collected at the Poteau River near Heavener station, with concentrations of all of the analyzed constituents in those samples being less than laboratory reporting levels. Additionally, numerous blank samples were analyzed for bacterial concentrations. Results of those analyses indicated little to no contamination during sampling or sample processing. 


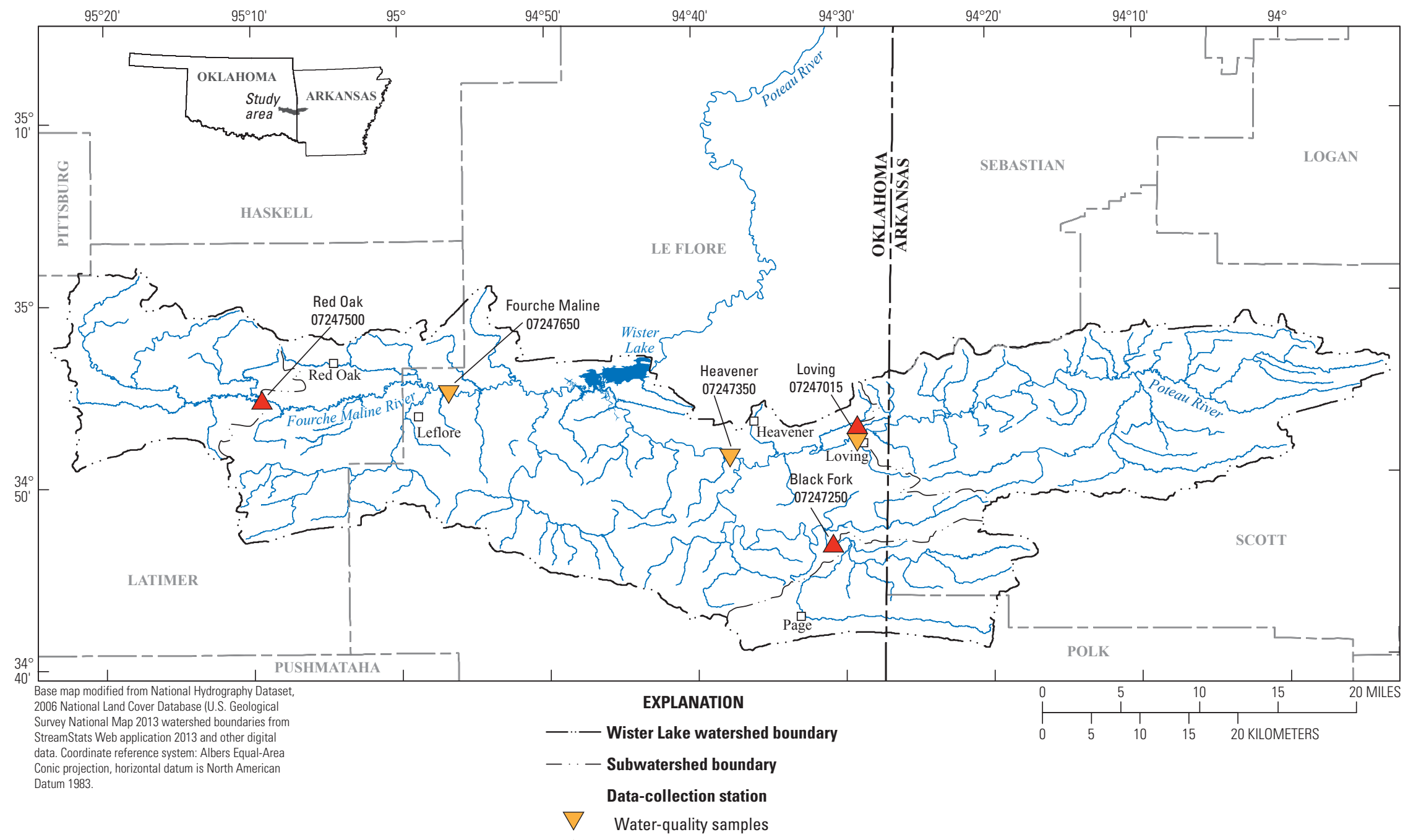

$\triangle$ Real-time streamflow at

streamflow-gaging station

Figure 3. The Wister Lake Basin, Oklahoma and Arkansas, and water-quality stations and streamflow-gaging stations that produced data used to compute streamflow for ungaged water-quality stations, 2011-13. 


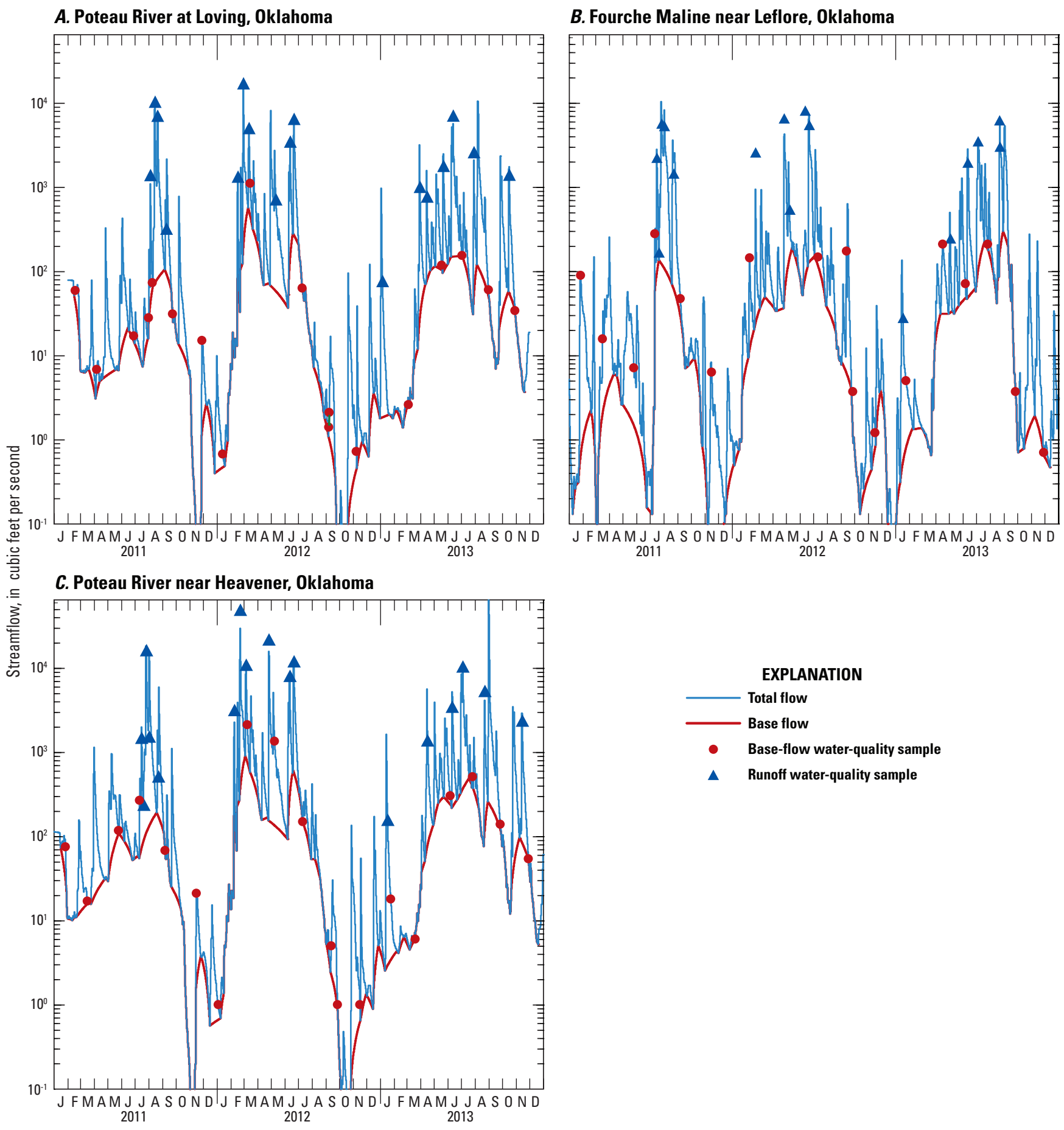

Figure 4. Streamflow separated into total flow, base flow, and the times and flows at which water-quality samples were collected at the $(A)$ Poteau River at Loving, Oklahoma; (B) Fourche Maline near Leflore, Okla.; and (C) Poteau River near Heavener, Okla., waterquality stations in the Wister Lake Basin, Oklahoma and Arkansas, 2010-13. 
Relative percent difference (RPD) was computed for analyzed concentrations between seven pairs of environmental and field sequential replicate samples (equation 1).

$$
R P D=\operatorname{abs}(D 1-D 2) / \operatorname{avg}(D 1+D 2) \times 100
$$

where

$$
\begin{aligned}
R P D & =\text { relative percent difference } \\
D 1 & =\text { measured value of the first duplicate } \\
D 2 & =\text { measured value of the second duplicate, } \\
\text { abs } & =\text { absolute value of } D 1-D 2, \text { and } \\
\text { avg } & =\text { mean value of } D 1 \text { and } D 2 .
\end{aligned}
$$

The median RPDs between sequential replicates analyzed for phosphorus and nitrogen concentrations were 3.5 and 1.9, respectively. The median RPD in the sediment concentration was 11.8. Bacterial quantification was more variable, with the median RPD for analyses of Escherichia coli being 21.1 and the median RPD for Enterococcus sp. being 28.6.

\section{Estimation of Daily Streamflow for Ungaged Water-Quality Stations}

Streamflow data at times other than sampling were not collected at two of the water-quality stations - Poteau River near Heavener, Okla., and Fourche Maline near Leflore, Okla.; however, streamflow data are required for computing annual and seasonal water-quality constituent loads with the S-LOADEST program (Cohn and others, 1989; Crawford, 1991). Streamflow data were therefore estimated for these two stations by using data collected at nearby streamflow-gaging stations operated by the USGS (fig. 3). The Drainage-Area Ratio Method, which can be used to estimate flow at ungaged stations with upstream or downstream gages (Ries and Friesz, 2000), was used to estimate daily flow data for the ungaged stations, as follows:

$$
Q_{\mathrm{s}}=\left[D A_{\mathrm{s}} / D A_{\mathrm{g}}\right] * Q_{\mathrm{g}}
$$

where

$$
\begin{aligned}
Q_{\mathrm{s}}= & \text { the daily mean streamflow at the ungaged } \\
& \text { station, in cubic feet per second; } \\
D A_{\mathrm{s}}= & \text { the drainage area of the ungaged station, in } \\
& \text { square miles; } \\
D A_{\mathrm{g}}= & \text { the drainage area of the gaging station } \\
& \text { (upstream or downstream), in square miles; } \\
& \text { and } \\
Q_{\mathrm{g}}= & \text { the daily mean streamflow at the gaging } \\
& \text { station (upstream or downstream) in cubic } \\
& \text { feet per second. }
\end{aligned}
$$

Daily mean streamflow at the Poteau River near Heavener, Okla., (fig. 3) was estimated by using the sum of daily streamflow at two upstream real-time streamflowgaging stations: Poteau River at Loving, Okla., (USGS station 07247015) and Black Fork below Big Creek near Page, Okla.
(USGS station 07247250). Daily mean streamflow for the Fourche Maline near Leflore, Okla., station was estimated by using the daily streamflow at the upstream station Fourche Maline near Red Oak, Okla. (USGS station 07247500) (fig. 3).

\section{Streamflow Separation}

Streamflow data were separated into base-flow and runoff components by using a hydrograph-separation program, Base-Flow Index (Institute of Hydrology, 1980a, 1980b; Wahl and Wahl, 1988). Base flow is streamflow that occurs during dry periods and is largely composed of groundwater seepage (Langbein and Iseri, 1960). Base-flow and runoff components were separated because water-quality-constituent concentrations collected during base-flow conditions are more indicative of the effects of point-source discharges, and constituent concentrations collected during runoff conditions are more indicative of discharges from nonpoint sources, with separation being useful for developing understanding of potential sources of these constituents (Tortorelli, 2008). By using the Base-Flow Index program, the minimum daily flow was identified in consecutive 5-day increments, and minimums smaller than 90 percent of adjacent minimums were defined as turning points (Wahl and Tortorelli, 1997). The Base-Flow Index program computes estimates of the base-flow hydrograph by connecting straight lines through consecutive turning points. Runoff components were calculated as the difference between total streamflow and the base-flow component.

\section{Load and Yield Estimation}

Load is the amount of a constituent transported past a given point of a stream per period of time, expressed in units of mass per unit of time. Instantaneous load can be computed as the product of instantaneous streamflow $(\mathrm{Q})$ and an instantaneous constituent concentration in water (C) multiplied by a conversion factor to convert cubic feet per second $\left(\mathrm{ft}^{3} / \mathrm{s}\right)$ and milligrams per liter $(\mathrm{mg} / \mathrm{L})$ into mass per unit of time. Similarly, seasonal or annual load can be computed as the product of seasonal or annual mean $\mathrm{Q}$ and seasonal or annual mean $\mathrm{C}$ if measured, but seasonal and annual mean $\mathrm{C}$ were not measured in this study because water-quality samples were only collected periodically. Linear regression was used, therefore, to estimate daily, seasonal, and annual mean constituent loads (total phosphorus, total nitrogen, and suspended sediment) from the periodically collected water-quality data and daily mean streamflow data. Constituent load is the dependent variable, and streamflow and time are the independent variables in such regressions. Regression methods require that daily mean streamflow and data from discrete water-quality samples be collected for several years (Runkel and others, 2004). Sample dates, times, continuous streamflow data, and total phosphorus, total nitrogen, and suspended sediment concentrations used in the regression analyses are provided in appendixes 1-3. 
The S-LOADEST program was used to fit parameters for linear regressions between constituent load and independent variables and then to estimate constituent loads at the sampled stations (Cohn and others, 1989; Crawford, 1991). S-LOADEST is based on the LOADEST program (Runkel and others, 2004) and has been incorporated in the statistical computer program S-Plus (Insightful Corporation, 2005) by the USGS to aid in graphical analysis and production of tabular results. S-LOADEST provides several options (for example, adjusted maximum likelihood method, least absolute deviation, Beale's ratio estimator) for applying regressions. Because the sample dataset for each constituent contained censored data (censored values are the values of the lower reporting level, reported with a "less than" remark code for samples in which the concentration was not detected), the adjusted maximum likelihood method was selected to estimate values of censored data for model computation (Dempster and others, 1977).

S-LOADEST contains nine predefined rating-curve models that can be used to test relations between constituent load and streamflow. For this study, two of the model equations were used. The first model (equation 3) was used to estimate loads of total phosphorus and total nitrogen and includes seasonality variables to simulate the relation between the natural logarithms of $\mathrm{L}$ and $\mathrm{Q}$ :

$$
\ln (\mathrm{L})=\mathrm{a}_{0}+\mathrm{a}_{1}{ }^{*} \ln \mathrm{Q}+\mathrm{a}_{2}{ }^{*} \sin \mathrm{SS}+\mathrm{a}_{3}{ }^{*} \cos \mathrm{SS}
$$

where

$$
\begin{aligned}
\ln = & \text { natural logarithm; } \\
\mathrm{L}= & \text { constituent load, in tons per day; } \\
\mathrm{a}_{0}, \mathrm{a}_{1}, \mathrm{a}_{2}, \mathrm{a}_{3}= & \text { regression coefficients, dimensionless; } \\
\mathrm{Q}= & \text { daily streamflow, in cubic feet per second; } \\
\sin = & \text { sine; } \\
\cos = & \text { cosine; and } \\
\mathrm{SS}= & \text { seasonality parameter }(2 * \text { pi*dectime, the } \\
& \text { time parameter in decimal years }) .
\end{aligned}
$$

The second model (equation 4) was used to estimate loads of suspended sediment and simulates the relation between the natural logarithms of $\mathrm{L}, \mathrm{Q}$, and $\mathrm{Q}^{2}$ :

$$
\ln (\mathrm{L})=\mathrm{a}_{0}+\mathrm{a}_{1}{ }^{*} \ln \mathrm{Q}+\mathrm{a}_{2}{ }^{*} \ln \mathrm{Q}^{2}
$$

where

$$
\begin{aligned}
\ln & =\text { natural logarithm; } \\
\mathrm{L} & =\text { constituent load, in tons per day; } \\
\mathrm{a}_{0}, \mathrm{a}_{1}, \mathrm{a}_{2} & =\text { regression coefficients, dimensionless; and } \\
\mathrm{Q} & =\text { daily streamflow, in cubic feet per second. }
\end{aligned}
$$

Estimated annual total phosphorus, total nitrogen, and suspended sediment loads and estimates of the standard deviations of the loads were calculated with S-LOADEST by using all data from water samples collected during baseflow and runoff conditions. The daily load values generated by S-LOADEST were separated into base-flow and runoff component sample sets according to the number of baseflow and runoff days for each water year (October 1 through September 30). Estimated annual base-flow loads were calculated as the sum of the values of the base-flow days sample sets. Estimated annual runoff loads were calculated as the sum of the values of the runoff days sample sets. The estimates of annual runoff load were biased slightly high, and the corresponding estimates of base-flow load were biased slightly low because a small fraction of the load on runoff days is from base flow, but because that fraction is small, the bias can be considered negligible. Estimated seasonal baseflow and runoff loads were calculated in the same manner, on the basis of the number of base-flow and runoff days in each season. In this report, the seasons are described as follows: (1) spring is March through May, (2) summer is June through August, (3) autumn is September through November, and (4) winter is December through February. Yields of total phosphorus, total nitrogen, and suspended sediment for the study period at each station were calculated by dividing annual loads of total phosphorus, total nitrogen, and suspended sediment by upstream drainage-basin area.

\section{Assessment of Concentrations, Loads, and Yields of Total Phosphorus, Total Nitrogen, and Suspended Sediment and Bacteria Concentrations in the Wister Lake Basin}

In this section, concentrations, loads, and yields of total phosphorus, total nitrogen, and suspended sediment are described for the three sampled stations in the Wister Lake Basin for water years 2011-13. Bacteria (Escherichia coli and Enterococcus sp.) concentrations collected during base-flow and runoff conditions also are described. All annual and seasonal loads, yields, and concentrations are based on estimated daily values of those statistics calculated by using the S-LOADEST program.

\section{Concentrations}

This section describes total phosphorus, total nitrogen, suspended sediment, and bacteria (Escherichia coli and Enterococcus sp.) concentrations in water-quality samples collected during base-flow and runoff conditions. Summary statistics of those data were computed for all samples collected from water years 2011 through 2013 and were divided into samples collected during base-flow and runoff conditions (table 2). For constituent results with censored data (marked with a less than symbol $[<]$ ), a distributional method called the maximum likelihood method (MLE) was used to estimate summary statistics (Helsel and Hirsch, 1992). Total nitrogen concentration and bacteria concentrations were the only 
Table 2. Summary statistics of total phosphorus, total nitrogen, suspended sediment, Escherichia coli, and Enterococcus sp. concentrations in water-quality samples collected during base-flow and runoff conditions at water-quality stations in the Wister Lake Basin, Oklahoma and Arkansas, October 2010 through September 2013.

[obs., number of observations; $\mathrm{mg} / \mathrm{L}$, milligrams per liter; $\mathrm{mL}$, milliliters; $<$, less than; >, greater than]

\begin{tabular}{|c|c|c|c|c|c|c|c|c|c|c|}
\hline \multirow{3}{*}{$\begin{array}{l}\text { Station name } \\
\text { (number) }\end{array}$} & \multicolumn{4}{|c|}{ Base-flow concentrations } & \multirow{3}{*}{ obs. } & \multicolumn{4}{|c|}{ Runoff concentrations } & \multirow{3}{*}{ obs. } \\
\hline & Minimum & Median & Mean & Maximum & & Minimum & Median & Mean & Maximum & \\
\hline & \multicolumn{4}{|c|}{$\begin{array}{l}\text { Total phosphorus } \\
\text { (mg/L as } \mathrm{P})\end{array}$} & & \multicolumn{4}{|c|}{$\begin{array}{l}\text { Total phosphorus } \\
\quad(\mathrm{mg} / \mathrm{L} \text { as } \mathrm{P})\end{array}$} & \\
\hline $\begin{array}{l}\text { Poteau River at Loving, Okla. } \\
\quad(07247015)\end{array}$ & 0.043 & 0.055 & 0.065 & 0.152 & 17 & 0.06 & 0.279 & 0.273 & 0.461 & 18 \\
\hline $\begin{array}{l}\text { Fourche Maline near } \\
\quad \text { Leflore, Okla. }(07247650)\end{array}$ & 0.04 & 0.069 & 0.069 & 0.096 & 11 & 0.034 & 0.142 & 0.176 & 0.717 & 24 \\
\hline
\end{tabular}

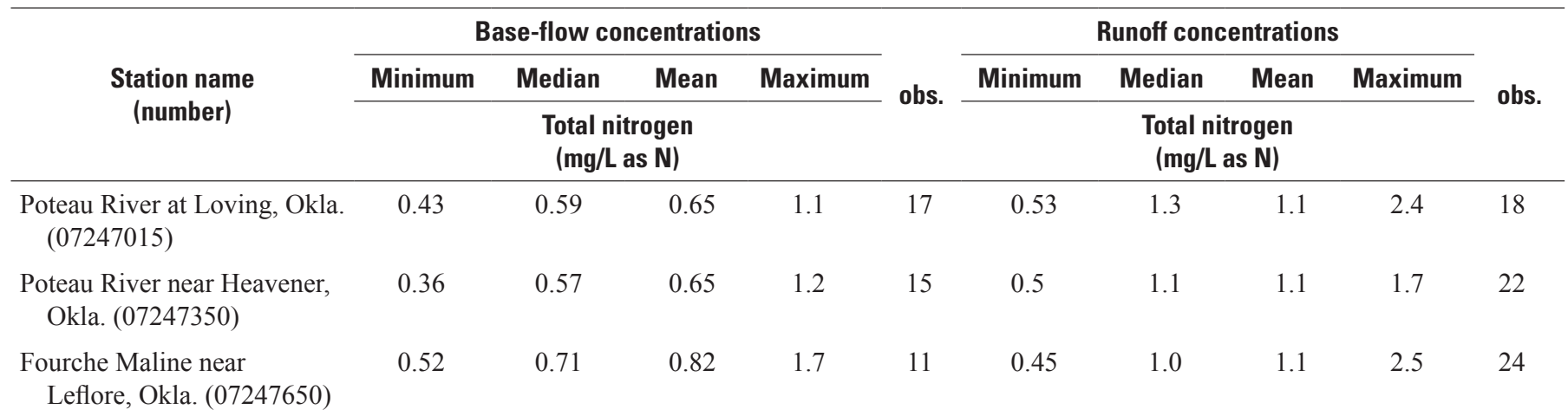

\begin{tabular}{|c|c|c|c|c|c|c|c|c|c|c|}
\hline \multirow{3}{*}{$\begin{array}{l}\text { Station name } \\
\text { (number) }\end{array}$} & \multicolumn{4}{|c|}{ Base-flow concentrations } & \multirow{3}{*}{ obs. } & \multicolumn{4}{|c|}{ Runoff concentrations } & \multirow{3}{*}{ obs. } \\
\hline & Minimum & Median & Mean & Maximum & & Minimum & Median & Mean & Maximum & \\
\hline & \multicolumn{4}{|c|}{$\begin{array}{l}\text { Suspended sediment } \\
(\mathrm{mg} / \mathrm{L})\end{array}$} & & \multicolumn{4}{|c|}{$\begin{array}{l}\text { Suspended sediment } \\
\text { (mg/L) }\end{array}$} & \\
\hline $\begin{array}{l}\text { Poteau River at Loving, Okla. } \\
\quad(07247015)\end{array}$ & 3 & 11 & 11 & 28 & 16 & 10 & 84 & 134 & 554 & 16 \\
\hline $\begin{array}{l}\text { Fourche Maline near } \\
\quad \text { Leflore, Okla. }(07247650)\end{array}$ & 9 & 27 & 33 & 71 & 10 & 10 & 74 & 146 & 820 & 20 \\
\hline
\end{tabular}

\begin{tabular}{|c|c|c|c|c|c|c|c|c|c|c|}
\hline \multirow{3}{*}{$\begin{array}{l}\text { Station name } \\
\text { (number) }\end{array}$} & \multicolumn{4}{|c|}{ Base-flow concentrations } & \multirow{3}{*}{ obs. } & \multicolumn{4}{|c|}{ Runoff concentrations } & \multirow{3}{*}{ obs. } \\
\hline & Minimum & Median & Mean & Maximum & & Minimum & Median & Mean & Maximum & \\
\hline & \multicolumn{4}{|c|}{ Escherichia coli per $100 \mathrm{~mL}$ of water } & & \multicolumn{4}{|c|}{ Escherichia coli per $100 \mathrm{~mL}$ of water } & \\
\hline $\begin{array}{l}\text { Poteau River near Heavener, } \\
\text { Okla. }(07247350)\end{array}$ & $<10$ & 26 & 54 & 250 & 14 & 41 & 2,050 & 2,443 & 9,900 & 22 \\
\hline
\end{tabular}


Table 2. Summary statistics of total phosphorus, total nitrogen, suspended sediment, Escherichia coli, and Enterococcus sp. concentrations in water-quality samples collected during base-flow and runoff conditions at water-quality stations in the Wister Lake Basin, Oklahoma and Arkansas, October 2010 through September 2013.-Continued

[obs., number of observations; mg/L, milligrams per liter; $\mathrm{mL}$, milliliters; $<$, less than; $>$, greater than]

\begin{tabular}{|c|c|c|c|c|c|c|c|c|c|c|}
\hline \multirow{3}{*}{$\begin{array}{l}\text { Station name } \\
\text { (number) }\end{array}$} & \multicolumn{4}{|c|}{ Base-flow concentrations } & \multirow{3}{*}{ obs. } & \multicolumn{4}{|c|}{ Runoff concentrations } & \multirow{2}{*}{ obs. } \\
\hline & Minimum & Median & Mean & Maximum & & Minimum & Median & Mean & Maximum & \\
\hline & \multicolumn{4}{|c|}{ Enterococcus sp. colonies per $100 \mathrm{~mL}$ of water } & & \multicolumn{5}{|c|}{ Enterococcus sp. colonies per $100 \mathrm{~mL}$ of water } \\
\hline $\begin{array}{l}\text { Poteau River at Loving, } \\
\text { Okla. (07247015) }\end{array}$ & 13 & 260 & 978 & $>4,800$ & 13 & 40 & 4,800 & 3,424 & $>4,800$ & 18 \\
\hline $\begin{array}{l}\text { Poteau River near Heavener, } \\
\text { Okla. }(07247350)\end{array}$ & 4 & 18 & 72 & 500 & 14 & $<2$ & 3,200 & 2,706 & $>4,800$ & 22 \\
\hline $\begin{array}{l}\text { Fourche Maline near } \\
\text { Leflore, Okla. }(07247650)\end{array}$ & 32 & 74 & 153 & 820 & 10 & 27 & 1,750 & 2,170 & $>4,800$ & 24 \\
\hline
\end{tabular}

constituents with censored data. The Wilcoxon rank-sum test was used to determine statistical significance of differences between samples collected during base-flow conditions and samples collected during runoff conditions, with significant differences in locations of distribution of datasets in this report being indicated by $p$-values $<0.05$ (Helsel and Hirsch, 1992).

\section{Total Phosphorus}

Total phosphorus concentrations in water samples collected during runoff conditions (fig. 5 , table 2) were significantly larger $(p \leq 0.05)$ than concentrations in samples collected during base-flow conditions at all stations except Fourche Maline for the 3-year study period. The smallest base-flow concentration of total phosphorus of $0.023 \mathrm{mg} / \mathrm{L}$ was measured in a water sample collected at the Poteau River near Heavener, Okla., station (table 2). The smallest total phosphorus concentration of $0.034 \mathrm{mg} / \mathrm{L}$ during runoff conditions was measured in a water sample collected at the Fourche Maline near Leflore, Okla., station. The largest total phosphorus concentration collected during base-flow conditions of $0.152 \mathrm{mg} / \mathrm{L}$ was measured in a water sample collected at the Poteau River at Loving, Okla., station, and the largest total phosphorus concentration of $0.717 \mathrm{mg} / \mathrm{L}$ collected during runoff conditions was measured in a water sample collected at the Fourche Maline near Leflore, Okla., station (table 2).

\section{Total Nitrogen}

Total nitrogen concentrations measured in water samples collected during runoff conditions (fig. 6 , table 2 ) were significantly larger $(p \leq 0.05)$ than total nitrogen concentrations in water samples collected during base-flow conditions at all stations except at the Fourche Maline near Leflore, Okla., station during the 3-year study period. Total nitrogen concentrations in water samples collected during base-flow conditions at the Fourche Maline near Leflore, Okla., station generally were larger than concentrations in the water samples collected at the Poteau River stations during baseflow conditions. The smallest total nitrogen concentration of $0.36 \mathrm{mg} / \mathrm{L}$ measured at base-flow conditions was measured in a water sample collected at the Poteau River near Heavener, Okla., station, and the smallest total nitrogen concentration of $0.45 \mathrm{mg} / \mathrm{L}$ was measured at runoff conditions in a water sample collected at the Fourche Maline near Leflore, Okla., station (table 2). The largest total nitrogen concentration at base-flow conditions $(1.7 \mathrm{mg} / \mathrm{L})$ and the largest total nitrogen concentration at runoff conditions $(2.5 \mathrm{mg} / \mathrm{L})$ were measured in water samples collected at the Fourche Maline near Leflore, Okla., station (table 2).

\section{Suspended Sediment}

Suspended sediment concentrations (fig. 7, table 2) were significantly larger $(p \leq 0.05)$ in water samples collected during runoff conditions than in water samples collected at baseflow conditions at all stations except at the Fourche Maline station during the 3-year study period. Suspended sediment concentrations in water samples collected at base-flow conditions at the Fourche Maline near Leflore, Okla., station generally were larger than in water samples collected during base-flow conditions at the Poteau River stations.

The smallest suspended sediment concentration in water samples collected during base-flow conditions $(3 \mathrm{mg} / \mathrm{L})$ was measured in water samples collected at the Poteau River stations (table 2). The smallest suspended sediment concentration in water samples collected during runoff conditions $(10 \mathrm{mg} / \mathrm{L})$ was measured in a water sample collected at the Poteau River at Loving, Okla., and the Fourche Maline near Leflore, Okla., stations. The smallest suspended sediment concentration in water samples collected during runoff conditions was only slightly larger at the Poteau River near Heavener, Okla., station (11 mg/L). The largest 


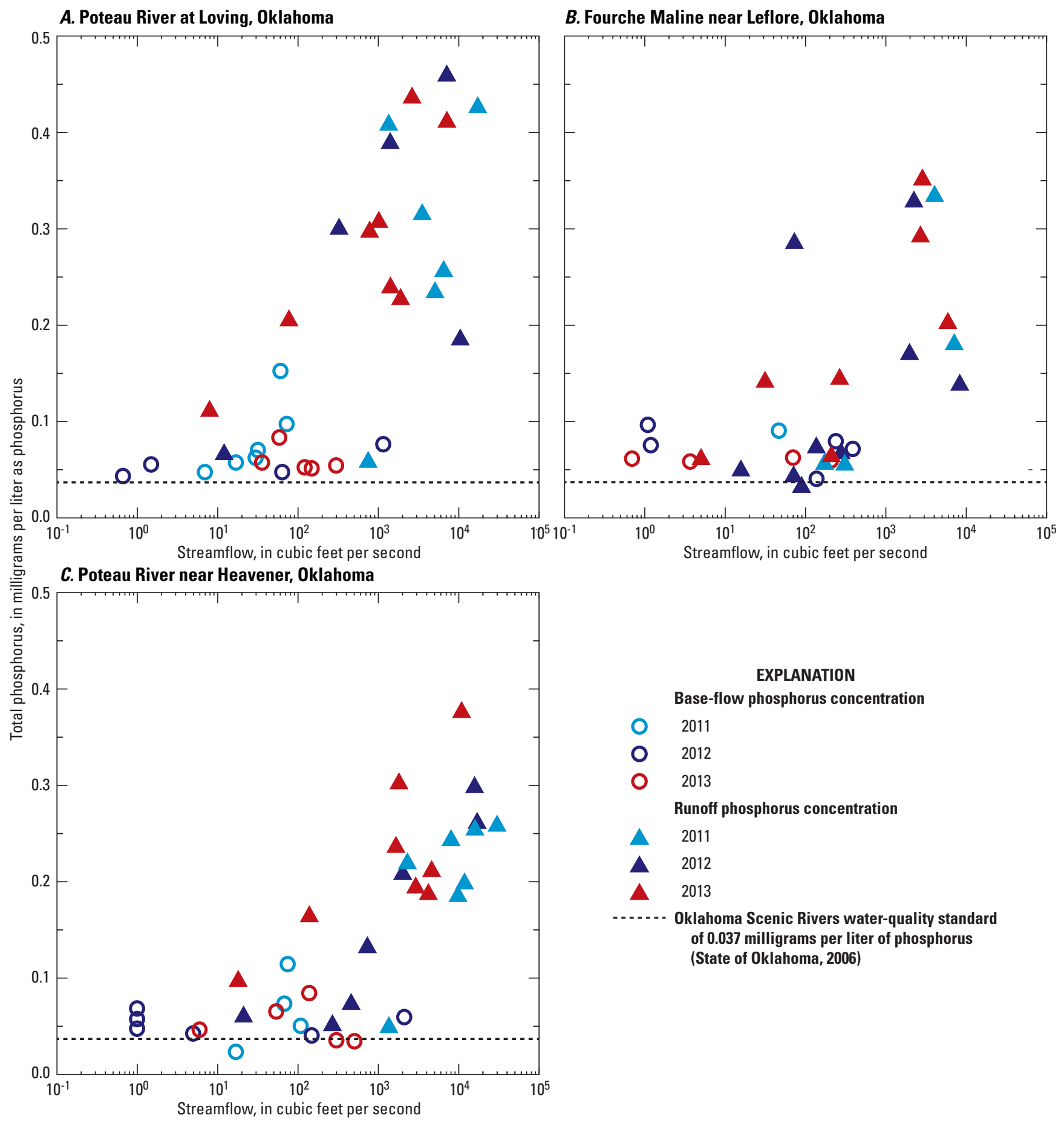

Figure 5. Total phosphorus concentrations in water-quality samples collected during base-flow and runoff conditions at the $(A)$ Poteau River at Loving, Oklahoma; (B) Fourche Maline near Leflore, Okla.; and (C) Poteau River near Heavener, Okla., water-quality stations in the Wister Lake Basin, Oklahoma and Arkansas, October 2010 through September 2013. 


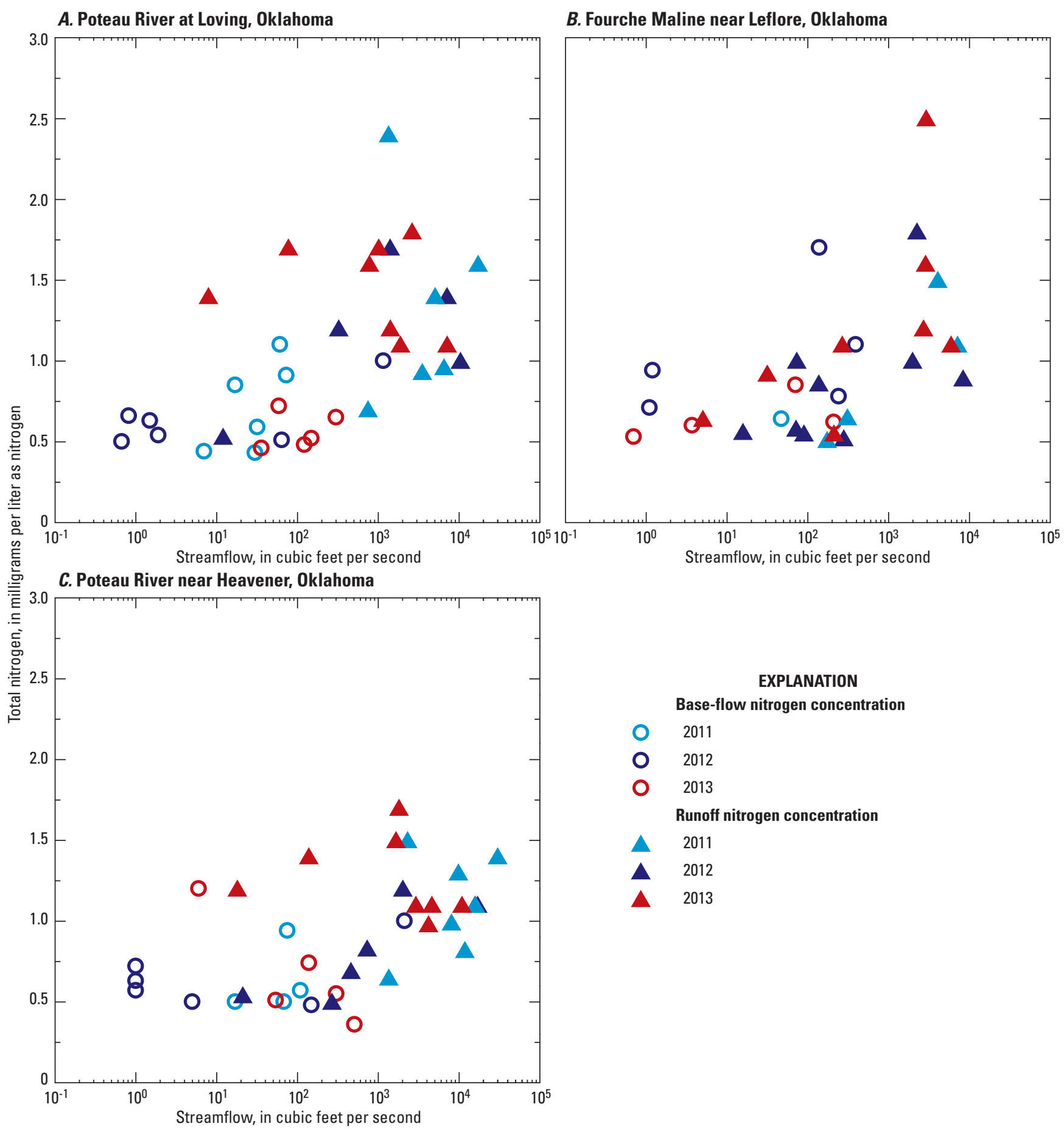

Figure 6. Total nitrogen concentrations in water-quality samples collected during base-flow and runoff conditions at the $(A)$ Poteau River at Loving, Oklahoma; (B) Fourche Maline near Leflore, Okla.; and $(C)$ Poteau River near Heavener, Okla., water-quality stations in the Wister Lake Basin, Oklahoma and Arkansas, October 2010 through September 2013. 
A. Poteau River at Loving, 0klahoma

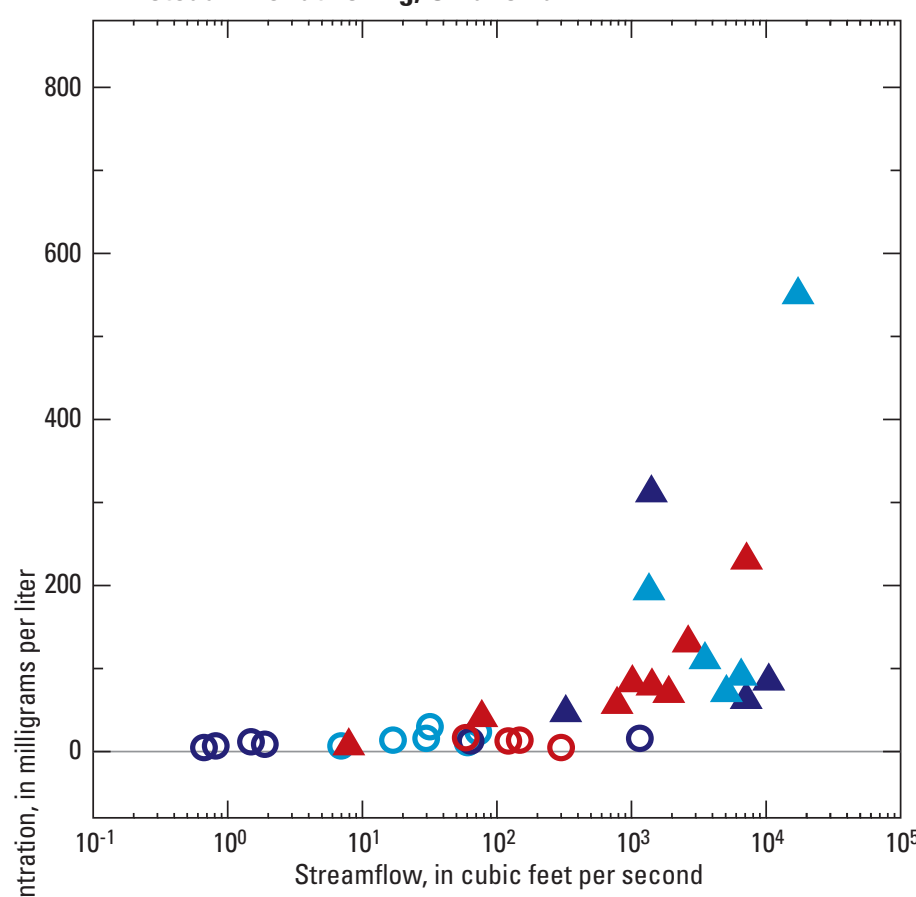

\section{Poteau River near Heavener, Oklahoma}

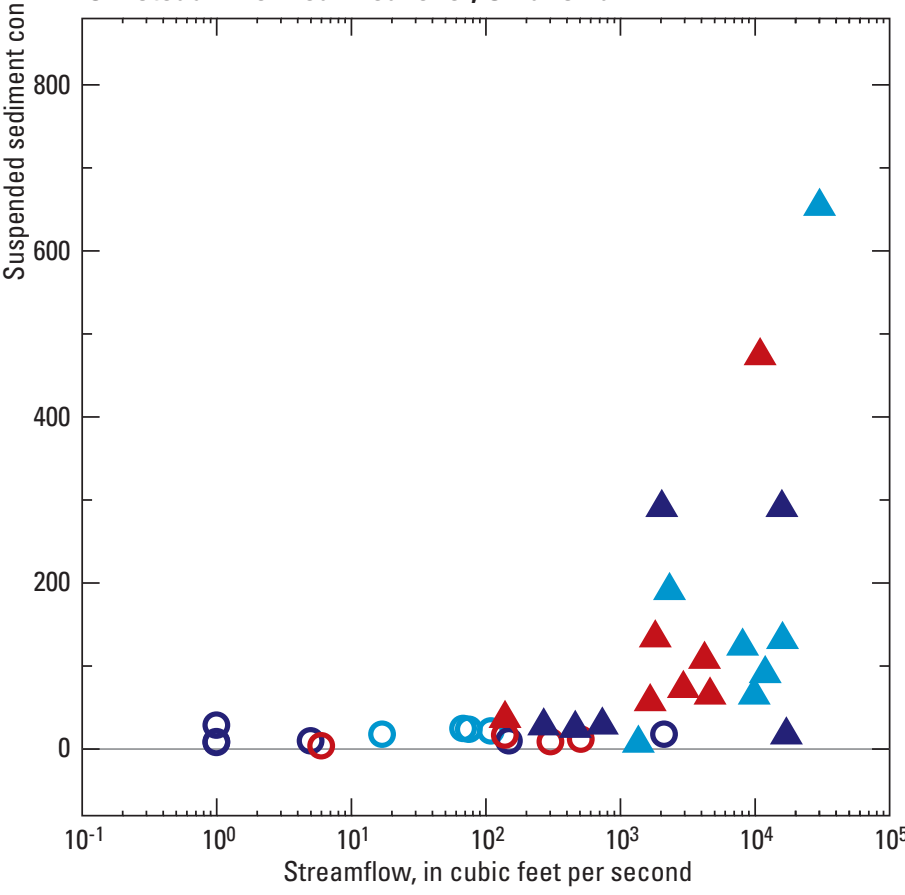

\section{B. Fourche Maline near Leflore, Oklahoma}

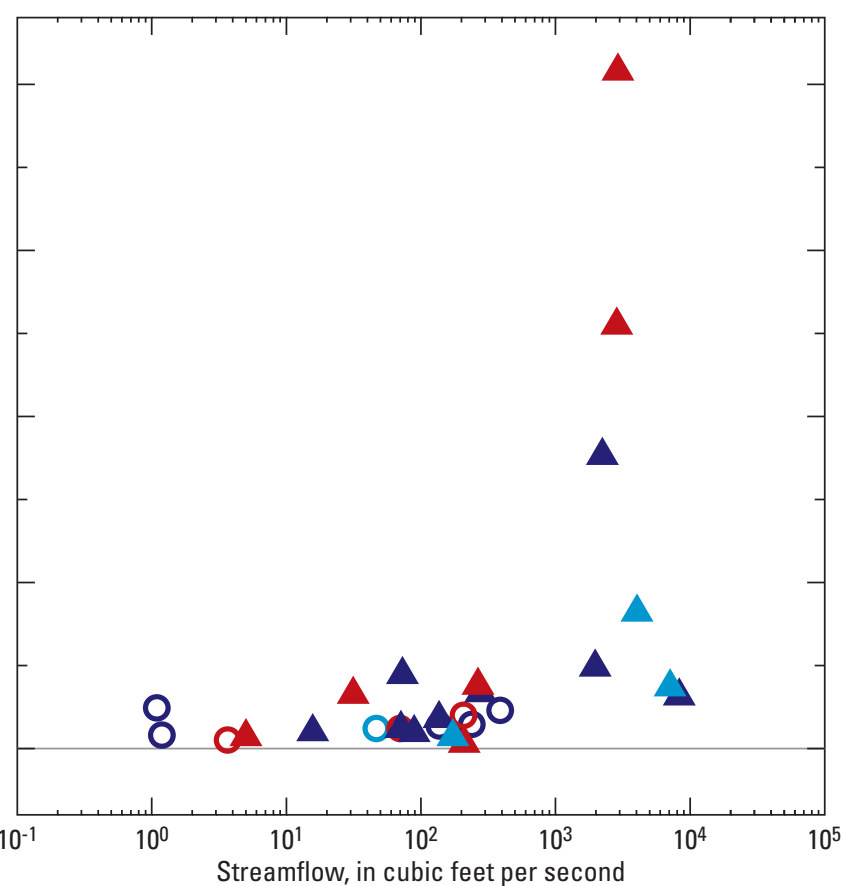

\section{EXPLANATION}

Base-flow sediment concentration

O 2011

O 2012

O 2013

Runoff sediment concentration

- 2011

A 2012

2013

Figure 7. Suspended sediment concentrations in water-quality samples collected during base-flow and runoff conditions at the $(A)$ Poteau River at Loving, Oklahoma; $(B)$ Fourche Maline near Leflore, Okla.; and $(C)$ Poteau River near Heavener, Okla., water-quality stations in the Wister Lake Basin, Oklahoma and Arkansas, October 2010 through September 2013. 
suspended sediment concentration measured in water samples collected at base-flow conditions $(71 \mathrm{mg} / \mathrm{L})$ and the largest suspended sediment concentration in water samples collected during runoff conditions $(820 \mathrm{mg} / \mathrm{L})$ were in samples collected at the Fourche Maline near Leflore, Okla., station (table 2).

\section{Bacteria}

Concentrations of Escherichia coli (fig. 8, table 2) were significantly larger $(p \leq 0.05)$ in water samples collected during runoff conditions than during base-flow conditions at these three stations. In water samples collected during base-flow conditions, Escherichia coli bacteria concentrations decreased in the downstream direction (Loving to Heavener, Okla.) at the two Poteau River stations. At the Fourche Maline near Leflore, Okla., station, bacteria concentrations collected during base-flow conditions were not significantly larger ( $\mathrm{p}$ is greater than $[>] 0.05$ ) than concentrations measured in water samples collected in base-flow conditions at the Poteau River stations. In water samples collected during runoff conditions, Escherichia coli concentrations decreased in the downstream direction (Loving to Heavener) in water samples collected at the Poteau River stations. During runoff conditions, Escherichia coli bacteria concentrations generally were larger in water samples collected at the Poteau River stations than at the Fourche Maline near Leflore, Okla., station. The smallest Escherichia coli bacteria concentration in water samples collected at all stations during base-flow conditions was smaller than the detection limit $(<10$ colonies per 100 milliliters [mL], table 2). During base-flow conditions, the largest Escherichia coli bacteria concentration (490 colonies per $100 \mathrm{~mL}$ ) was measured in a water sample collected at the Fourche Maline near Leflore, Okla., station. That concentration of Escherichia coli bacteria was larger than the Oklahoma State Standard for Primary Body Contact Recreation of 126 colonies per $100 \mathrm{~mL}$ (geometric mean of no less than five samples per 30 days) (State of Oklahoma, 2006). The largest measured Escherichia coli bacteria concentration $(24,000$ colonies per $100 \mathrm{~mL})$ was measured in a water sample collected during runoff conditions at the Fourche Maline near Leflore, Okla., station (table 2).

Concentrations of Enterococcus sp. bacteria (fig. 9, table 2$)$ were significantly larger $(p \leq 0.05)$ in water samples collected during runoff conditions than in water samples collected during base-flow conditions at the three sampled stations. Concentrations of Enterococcus sp. bacteria in water samples collected at base-flow conditions were largest at the Poteau River at Loving, Okla., station. Concentrations of Enterococcus sp. bacteria concentrations in water samples collected during runoff conditions at the two Poteau River stations generally were larger than in water samples collected during runoff conditions at the Fourche Maline near Leflore, Okla., station. The smallest measured concentration of Enterococcus sp. bacteria (4 colonies per
$100 \mathrm{~mL}$ ) was measured in a water sample collected during base-flow conditions at the Poteau River near Heavener, Okla., station (table 2). The largest concentration of Enterococcus sp. bacteria in water samples collected during base-flow conditions $(>4,800$ colonies per $100 \mathrm{~mL})$ was measured at the Poteau River at Loving, Okla., station. Some water samples collected at baseflow conditions and most water samples collected at runoff conditions contained Enterococcus sp. bacteria concentrations exceeding the Oklahoma State Primary Body Contact Recreation of 33 colonies per $100 \mathrm{~mL}$ (which is based on a geographic mean of samples) (fig. 9; State of Oklahoma, 2006). The smallest Enterococcus sp. bacteria concentration measured during runoff conditions was less than the detection limit $(<2$ colonies per $100 \mathrm{~mL}$ ) in a water sample collected at the Poteau River near Heavener, Okla., station (table 2). The largest Enterococcus sp. bacteria concentration measured in water samples collected during runoff conditions exceeded the maximum detection limit of 4,800 colonies per $100 \mathrm{~mL}$ at each of these stations.

\section{Seasonal Variation of Concentration}

Total phosphorus, total nitrogen, and suspended sediment concentrations in these streams varied throughout the year, probably affected by a combination of factors such as precipitation amounts, land use in the upstream basins, ground cover in pastures, and streamflow. Total phosphorus and nitrogen concentrations can vary seasonally on the basis of timing of fertilizer and manure applications in addition to variable precipitation amounts (Storm and others, 2001). These factors increase the probability of larger phosphorus and nitrogen concentrations in streams during runoff conditions during the growing season (spring and summer); however, relatively large total phosphorus and nitrogen concentrations also were measured in these streams during base-flow conditions. Total phosphorus and nitrogen concentrations in streams downstream from urban areas may be larger during seasonal base flow when effluents from point sources such as WWT plants compose a substantial part of streamflow and dilution of those discharges is relatively small (U.S. Geological Survey, 1999). Suspended sediment concentration can vary seasonally, partly on the basis of the amount of ground cover in pastures during the nongrowing seasons (autumn and winter), when increased sediment runoff can occur (Wilson, 1972).

\section{Estimated Annual Loads}

Estimated annual loads of total phosphorus, total nitrogen, and suspended sediment for the three stations sampled for this report from 2011 to 2013 are described in this section. Total annual loads were divided into base-flow and runoff components. Linear regression models developed 


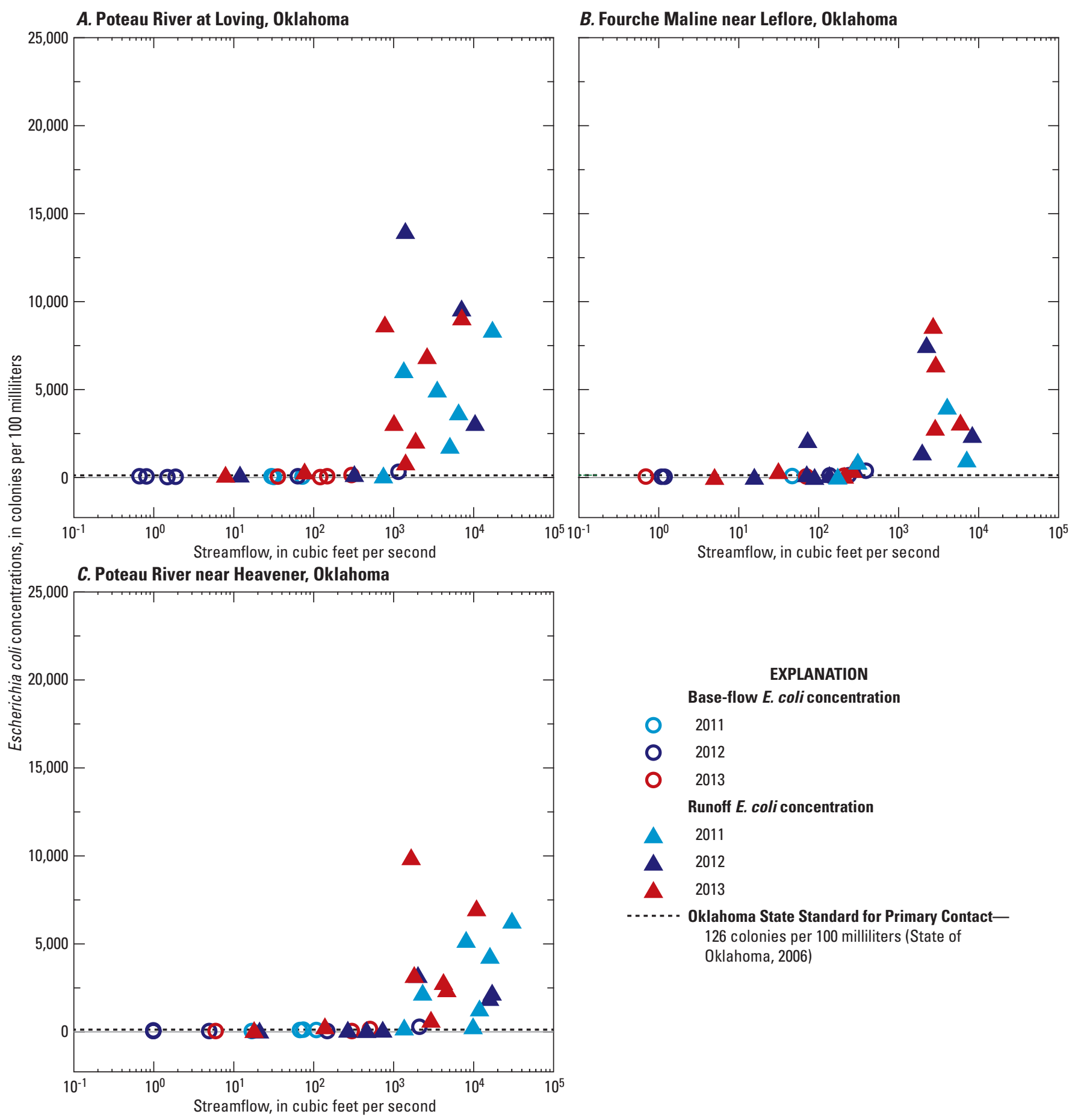

Figure 8. Total Escherichia coli bacteria concentrations in water-quality samples collected during base-flow and runoff conditions at the $(A)$ Poteau River at Loving, Oklahoma; $(B)$ Fourche Maline near Leflore, Okla.; and $(C)$ Poteau River near Heavener, Okla., waterquality stations in the Wister Lake Basin, Oklahoma and Arkansas, October 2010 through September 2013. 


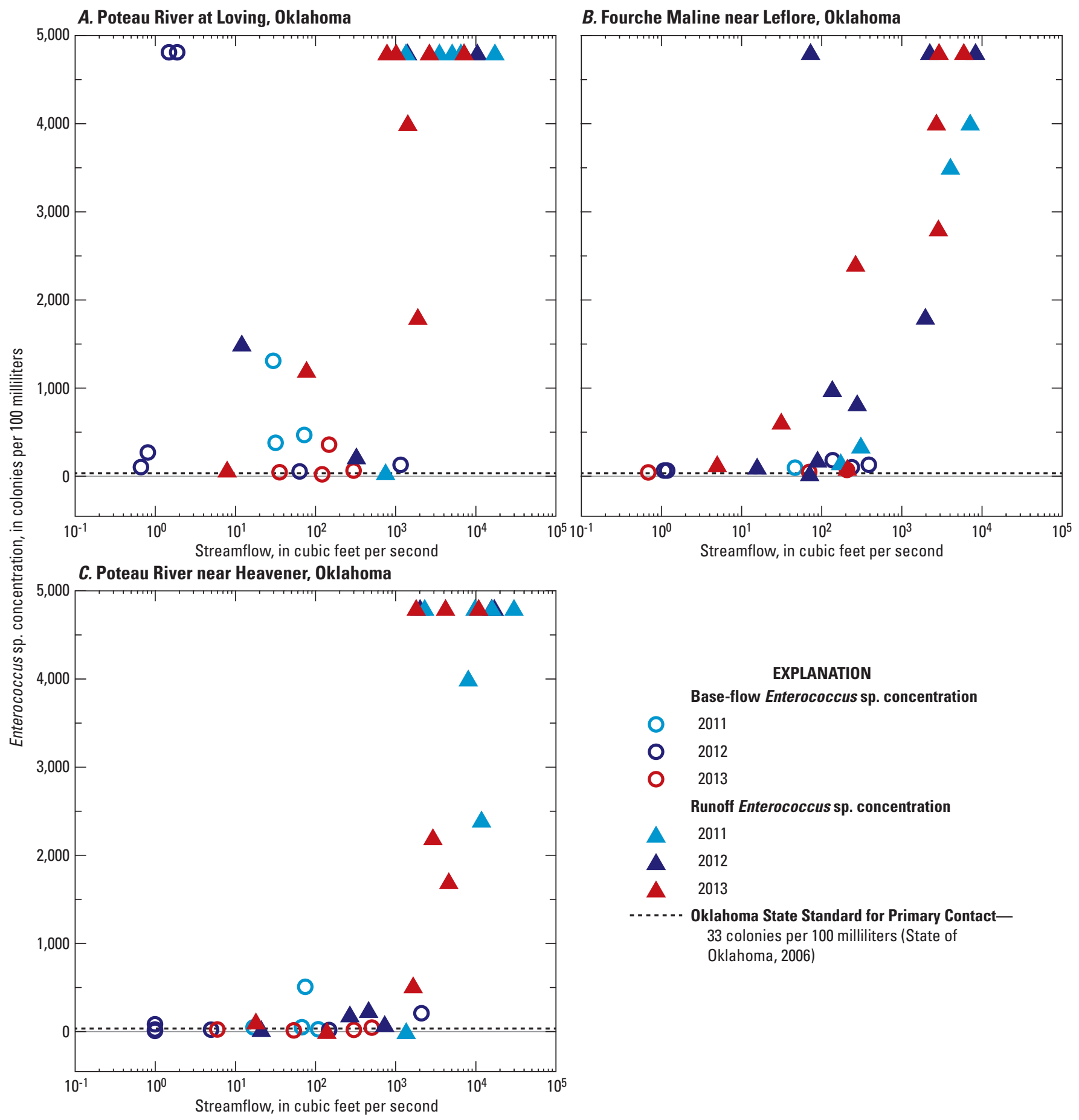

Figure 9. Enterococcus sp. bacteria concentrations in water-quality samples collected during base-flow and runoff conditions at the (A) Poteau River at Loving, Oklahoma; (B) Fourche Maline near Leflore, Okla.; and (C) Poteau River near Heavener, Okla., water-quality stations in the Wister Lake Basin, Oklahoma and Arkansas, October 2010 through September 2013. 
by S-LOADEST for the estimation of loads of phosphorus, nitrogen, and sediment at each station for water years 2011-13 are listed on table 3. In some cases, other S-LOADEST predefined regressions that used various combinations of streamflow, time, and seasonal coefficients had smaller residuals than the models used for this report; however, the "best-fit" model varied substantially among constituents and stations. Therefore, one general model was used to estimate loads of phosphorus and nitrogen (equation 3, shown earlier in this report) and sediment (equation 4, shown earlier in this report). The standard error of estimate (SEE) is the square root of residual variance. These log-transformed values, when multiplied by 100 , can be interpreted as average percent error. The actual percent error for the Poteau River near Heavener, Okla., and the Fourche Maline near Leflore, Okla., stations may be slightly higher because of the greater uncertainty of the streamflow values. LOADEST can produce biased results, and the load bias can be identified by analyzing the model residuals. The standard error of prediction (SEP) is the standard deviation of the estimated value from the observed value and measures the amount of variance among the distribution of the estimates (Runkel and others, 2004).

\section{Total Phosphorus}

Total phosphorus loads during runoff conditions composed 86 to 96 percent of the total annual phosphorus load at the Poteau River stations (table 4). Total phosphorus loads during runoff conditions composed 87 to 98 percent of the total estimated annual phosphorus loads at the Fourche Maline near Leflore, Okla., station (table 4). Annual total phosphorus runoff loads were smaller in water year 2011 than in the subsequent 2 years at the Poteau River stations but were slightly larger than in the subsequent 2 years at the Fourche Maline near Leflore, Okla., station (table 4).

\section{Total Nitrogen}

The runoff component of estimated total nitrogen loads at the Poteau River stations composed 82 to 91 percent of the total annual estimated total nitrogen load (table 5). Estimated runoff loads of total nitrogen at the Fourche Maline near Leflore, Okla., station composed 86 to 99 percent of the estimated total annual loads. The largest percentage of total nitrogen in runoff was estimated in 2011 at the three sampled stations during the 2011-13 study period (table 5).

Table 3. Regression models used for estimating total phosphorus, total nitrogen, and suspended sediment loads at water-quality stations sampled in the Wister Lake Basin, Oklahoma and Arkansas, October 2010 to September 2013.

[In, natural logarithm; L, daily load in tons per day; Q, mean daily streamflow in cubic feet per second; sin, sine; cos, cosine; SS, seasonality parameter $\left(2 * \mathrm{pi}^{*}\right.$ dectime). The standard error of the estimate is reported in natural logarithm units; therefore, this value, multiplied by 100 , can be interpreted roughly as the average percent error]

\begin{tabular}{|c|c|c|c|}
\hline Station name (number) & $\begin{array}{l}\text { Number of } \\
\text { observations }\end{array}$ & $\begin{array}{l}\text { Total phosphorus load } \\
\text { regression model }\end{array}$ & $\begin{array}{l}\text { Standard error } \\
\text { of the estimate } \\
\text { (In of tons) }\end{array}$ \\
\hline Poteau River at Loving, Okla. (07247015) & 36 & $\ln (\mathrm{L})=-3.24+1.26 * \ln \mathrm{Q}-0.23 * \sin \mathrm{SS}-0.16 * \cos \mathrm{SS}$ & 0.495 \\
\hline Poteau River near Heavener, Okla. (07247350) & 37 & $\ln (\mathrm{L})=-3.41+1.22 * \ln \mathrm{Q}-0.310 * \sin \mathrm{SS}-0.244 * \cos \mathrm{SS}$ & 0.511 \\
\hline Fourche Maline near Leflore, Okla. (07247650) & 38 & $\ln (\mathrm{L})=-4.96+1.18 * \ln \mathrm{Q}-0.23 * \sin \mathrm{SS}-0.18^{*} \cos \mathrm{SS}$ & 0.536 \\
\hline Station name (number) & $\begin{array}{c}\text { Number of } \\
\text { observations }\end{array}$ & $\begin{array}{l}\text { Total nitrogen load } \\
\text { regression model }\end{array}$ & $\begin{array}{c}\text { Standard error } \\
\text { of the estimate } \\
\text { (In of tons) }\end{array}$ \\
\hline Poteau River at Loving, Okla. (07247015) & 36 & $\ln (\mathrm{L})=-1.26+1.12 * \ln \mathrm{Q}-0.21 * \sin \mathrm{SS}+0.04 * \cos \mathrm{SS}$ & 0.358 \\
\hline Poteau River near Heavener, Okla. (07247350) & 37 & $\ln (\mathrm{L})=-1.26+1.09 * \ln \mathrm{Q}-0.26 * \sin \mathrm{SS}+0.12 * \cos \mathrm{SS}$ & 0.313 \\
\hline Station name (number) & $\begin{array}{l}\text { Number of } \\
\text { observations }\end{array}$ & $\begin{array}{l}\text { Suspended sediment load } \\
\text { regression model }\end{array}$ & $\begin{array}{c}\text { Standard error } \\
\text { of the estimate } \\
\text { (In of tons) }\end{array}$ \\
\hline Poteau River at Loving, Okla. (07247015) & 33 & $\ln (\mathrm{L})=1.95+1.41 * \ln \mathrm{Q}+0.014 * \ln \mathrm{Q}^{2}$ & 0.666 \\
\hline Poteau River near Heavener, Okla. (07247350) & 33 & $\ln (\mathrm{L})=2.12+1.32 * \ln \mathrm{Q}+0.23 * \ln \mathrm{Q}^{2}$ & 0.876 \\
\hline Fourche Maline near Leflore, Okla. (07247650) & 30 & $\ln (\mathrm{L})=-0.03+1.21 * \ln \mathrm{Q}+0.026 * \ln \mathrm{Q}^{2}$ & 0.722 \\
\hline
\end{tabular}




\section{Suspended Sediment}

Estimated suspended sediment loads at the Poteau River stations during runoff conditions composed 91 to 98 percent of the estimated total annual loads (table 6). At the Fourche Maline near Leflore, Okla., station, estimated suspended sediment loads during runoff conditions composed 91 to more than 99 percent of the total estimated annual suspended sediment loads (table 6). Annual runoff suspended sediment loads were largest in 2011-13 at the Poteau River near Heavener, Okla., station (table 6).

\section{Estimated Seasonal Loads}

Estimated seasonal total phosphorus, total nitrogen, and suspended sediment loads are described in this section. Those loads are divided into base-flow and runoff components (tables 7-9).

\section{Total Phosphorus}

Estimated seasonal loads of total phosphorus during base-flow conditions varied between the Poteau River stations and the Fourche Maline station in 2011-13 (table 7). At the Poteau River at Loving, Okla., station, the smallest estimated total phosphorus loads during base-flow conditions occurred in autumn (September through November). At the Poteau River at Heavener, Okla., station, the smallest estimated total phosphorus loads during base flow generally occurred during summer (June through August). At the Fourche Maline near LeFlore, Okla., station, the smallest estimated total phosphorus loads during base flow occurred in autumn (September through November). At the Poteau River stations, estimated total phosphorus loads at base-flow conditions typically were several times larger than at the Fourche Maline near Leflore, Okla., station (table 7). Estimated seasonal total phosphorus loads generally were largest in the winter during base-flow conditions.

Table 4. Estimated annual total phosphorus loads and yields in the Wister Lake Basin, Oklahoma and Arkansas, 0ctober 2010 through September 2013.

$\left[\mathrm{mi}^{2}\right.$, square mile; ton/yr, tons per year; ton $\cdot \mathrm{yr}^{-1} \cdot \mathrm{mi}^{-2}$, tons per year per square mile; SEP, standard error of prediction; P, phosphorus. Differences between baseflow loads plus runoff loads are due to rounding]

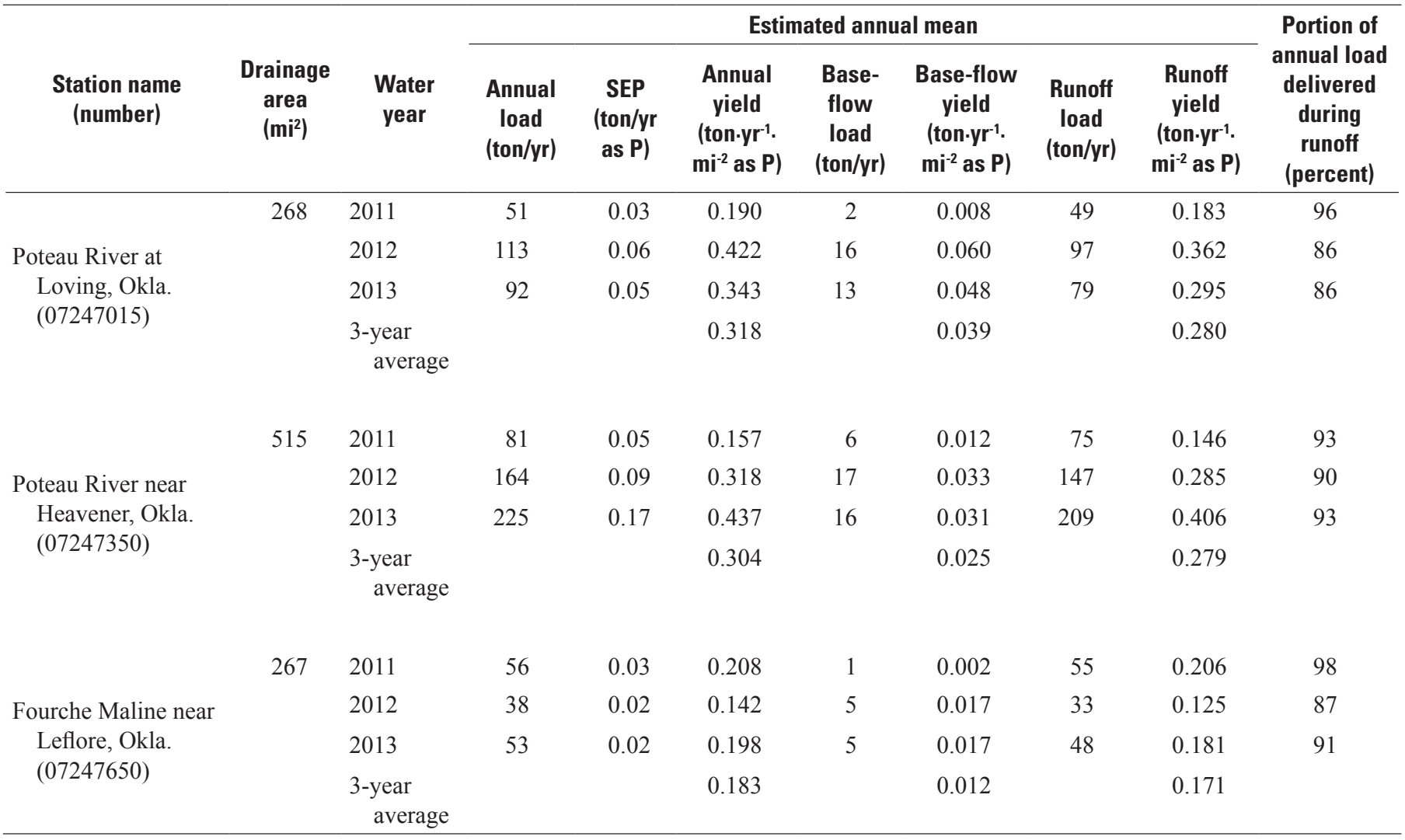


Table 5. Estimated annual total nitrogen loads and yields in the Wister Lake Basin, Oklahoma and Arkansas, October 2010 through September 2013.

$\left[\mathrm{mi}^{2}\right.$, square mile; ton/yr, tons per year; ton $\mathrm{yr}^{-1} \cdot \mathrm{mi}^{-2}$, tons per year per square mile; SEP, standard error of prediction; P, phosphorus. Differences between baseflow loads plus runoff loads are due to rounding]

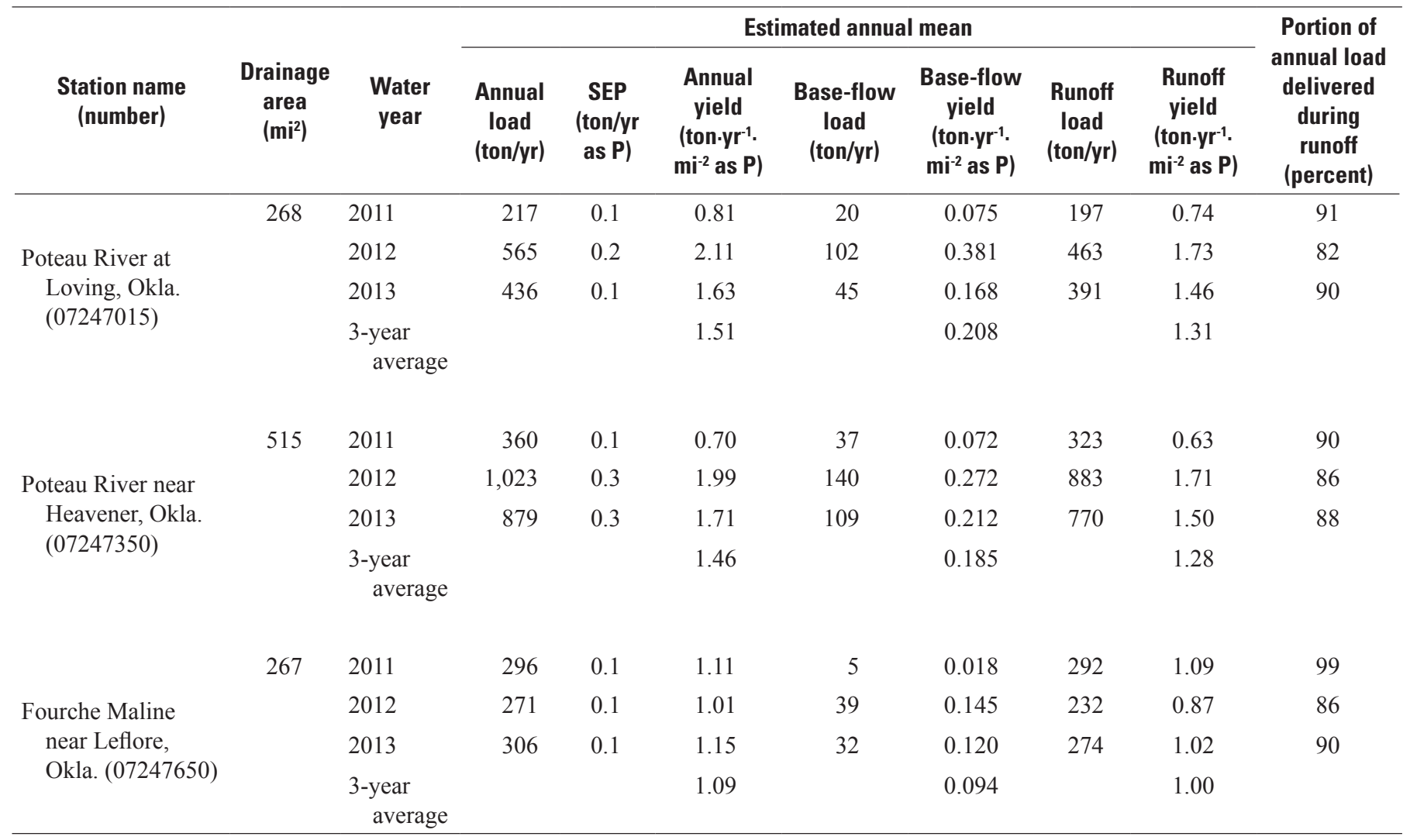

Estimated seasonal total phosphorus loads during runoff conditions typically were largest in spring (March through May) and smallest in autumn (September through November) at these three stations. Annual estimated total phosphorus seasonal loads typically were several times larger at the Poteau River stations than at the Fourche Maline near Leflore, Okla., station (table 7).

\section{Total Nitrogen}

Estimated seasonal loads of total nitrogen generally were largest at the Poteau River near Heavener, Okla., station for all seasons (table 8). Estimated seasonal total nitrogen loads during base-flow conditions generally were smallest during the autumn for all stations (table 8). The smallest total nitrogen loads during base-flow conditions were estimated at the Fourche Maline near Leflore, Okla., station in autumn. The majority of the total nitrogen was delivered to Wister Lake during runoff conditions in winter. At the Poteau River stations, estimated total nitrogen seasonal loads at base-flow conditions were several times larger than at the Fourche Maline near Leflore, Okla., station (table 8). Estimated total nitrogen seasonal loads during runoff conditions generally were largest in winter and spring for the Poteau River Stations and were largest during the spring at the Fourche Maline near Leflore, Okla., station (table 8).

\section{Suspended Sediment}

Estimated seasonal suspended sediment loads during base-flow conditions generally were smallest in the summer at the Poteau River stations and smallest in the autumn at the Fourche Maline near Leflore, Okla., station (table 9). The estimated seasonal suspended sediment loads at base-flow conditions generally were smallest at the Poteau River at Loving, Okla., station during summer. Estimated seasonal base-flow suspended sediment loads at the Poteau River stations typically were several times larger than at the Fourche Maline near Leflore, Okla., station (table 9).

Estimated seasonal suspended sediment loads during runoff conditions typically were largest in the spring and smallest during the autumn (table 9). Seasonal runoff suspended sediment loads at the Poteau River stations generally were larger than those estimated at the Fourche Maline near Leflore, Okla., station (table 9). 
Table 6. Estimated annual suspended sediment loads and yields in the Wister Lake Basin, Oklahoma and Arkansas, October 2010 through September 2013.

$\left[\mathrm{mi}^{2}\right.$, square mile; ton/yr, tons per year; ton $\cdot \mathrm{yr}^{-1} \cdot \mathrm{mi}^{-2}$, tons per year per square mile; SEP, standard error of prediction. Differences between base-flow loads and runoff loads are due to rounding; 99+, less than 100 percent]

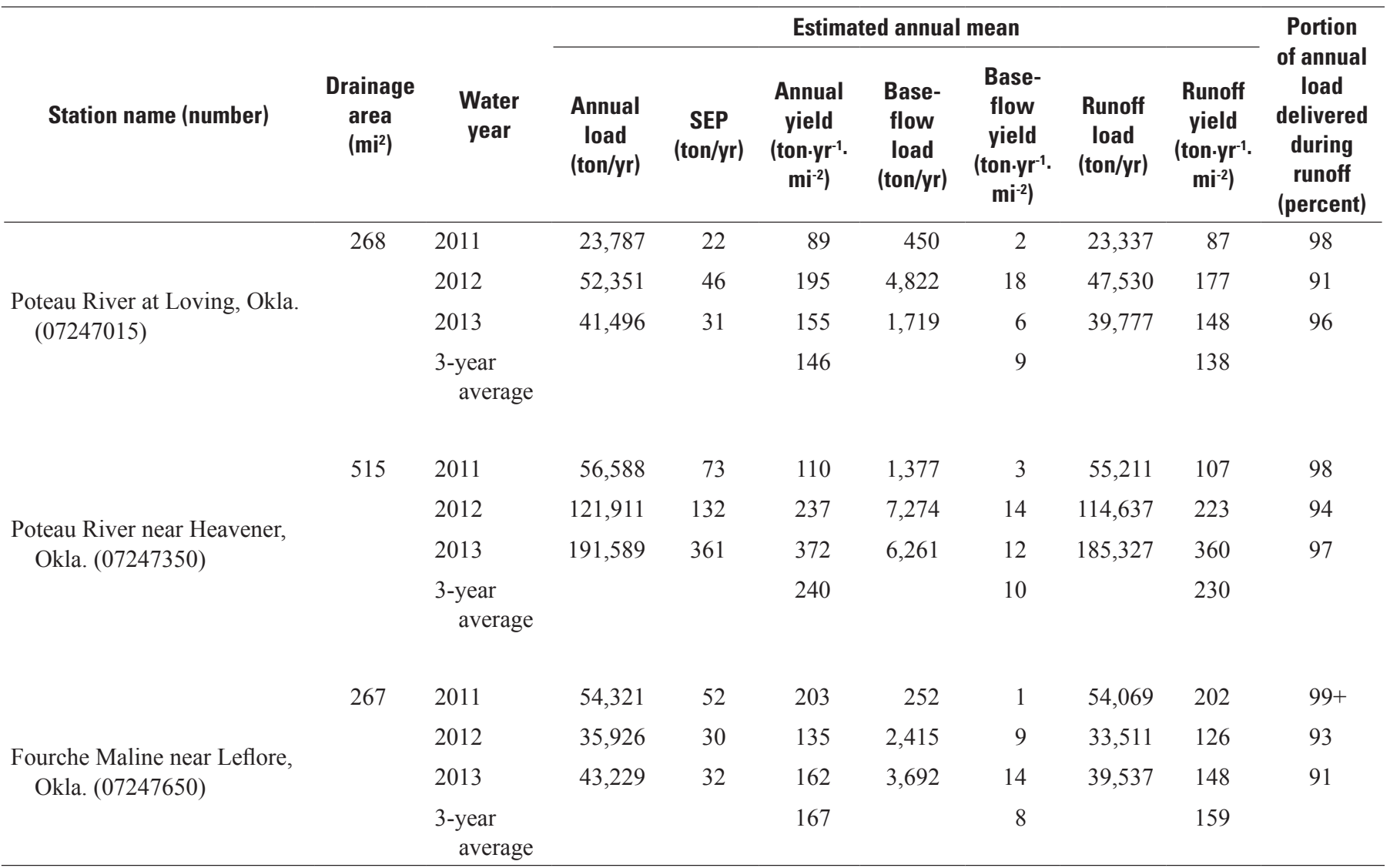

\section{Comparison of Estimated Annual Yields Among Stations}

Estimated annual yields for total phosphorus, total nitrogen, and suspended sediment for the three sampled stations in the Wister Lake Basin for the period 2011-13 are described in this section. The annual yields also are divided into base-flow and runoff components.

\section{Total Phosphorus}

Estimated annual total phosphorus yield slightly decreased in the downstream direction in 2011 and 2012 and increased slightly in the downstream direction (Loving to Heavener, Okla.) in 2013 at the Poteau River stations (table 4). Annual total phosphorus yield at the Fourche Maline near Leflore, Okla., station decreased from 2011 to 2012 and increased from 2012 to 2013 (table 4). Annual yields of total phosphorus ranged from 0.142 to 0.437 tons per year per square mile (ton $\left.\cdot \mathrm{yr}^{-1} \cdot \mathrm{mi}^{-2}\right)$ at these stations, with the largest mean annual yield estimated at the Poteau River near Heavener, Okla., station in 2013 and the smallest yield estimated at the Fourche Maline near Leflore, Okla., station in 2012 (table 4).

Estimated mean annual total phosphorus yields during base-flow conditions were largest at the Poteau River at Loving, Okla., station (table 4). The smallest mean annual yield during base-flow conditions was at the Fourche Maline near Leflore, Okla., station (table 4). Annual estimated total phosphorus yields during base-flow conditions at these stations ranged from 0.002 to 0.060 ton $\cdot \mathrm{yr}^{-1} \cdot \mathrm{mi}^{-2}$ (table 4).

Mean estimated yields during runoff conditions were largest at the Poteau River stations (table 4). Annual estimated total phosphorus yields during runoff conditions at the three sampled stations ranged from 0.125 to 0.406 ton $\cdot \mathrm{yr}^{-1} \cdot \mathrm{mi}^{-2}$ (table 4). The largest estimated total phosphorus yield during runoff conditions was at the Poteau River near Heavener, Okla., station in 2013, whereas the smallest estimated total phosphorus yield during runoff conditions was at the Fourche Maline near Leflore, Okla., station in 2012 (table 4). 
Table 7. Estimates of seasonal total phosphorus loads during base-flow and runoff conditions in the Wister Lake Basin, Oklahoma and Arkansas, October 2010 through September 2013.

[Values are loads in tons per season as phosphorus; spring is March through May, summer is June through August, autumn is September through November, and winter is December through February]

\begin{tabular}{|c|c|c|c|c|c|c|}
\hline \multirow[b]{2}{*}{ Flow type } & \multirow[b]{2}{*}{ Station name (number) } & \multicolumn{5}{|c|}{ Estimated seasonal total phosphorus loads } \\
\hline & & $\begin{array}{l}\text { Water } \\
\text { year }\end{array}$ & Spring & Summer & Autumn & Winter \\
\hline \multirow{3}{*}{ Base flow } & & 2011 & 1.06 & 0.30 & 0.79 & 0.15 \\
\hline & & 2012 & 2.50 & 0.01 & 1.76 & 11.50 \\
\hline & & 2013 & 3.95 & 7.76 & 0.03 & 1.55 \\
\hline \multirow{3}{*}{ Runoff } & & 2011 & 46.58 & 1.07 & 0.06 & 0.85 \\
\hline & & 2012 & 19.85 & 0.13 & 44.89 & 32.17 \\
\hline & & 2013 & 29.35 & 41.19 & 1.35 & 7.75 \\
\hline \multirow{4}{*}{ Base flow } & & 2011 & 1.92 & 0.81 & 0.99 & 0.77 \\
\hline & & 2012 & 4.45 & 0.01 & 2.74 & 9.90 \\
\hline & & 2013 & 9.51 & 2.85 & 0.06 & 3.18 \\
\hline & $\begin{array}{l}\text { Poteau River near Heavener, } \\
\text { Okla. }(07247350)\end{array}$ & & & & & \\
\hline \multirow{3}{*}{ Runoff } & & 2011 & 70.55 & 1.22 & 0.13 & 2.74 \\
\hline & & 2012 & 31.73 & 0.18 & 61.63 & 53.59 \\
\hline & & 2013 & 110.60 & 85.64 & 1.86 & 10.97 \\
\hline \multirow{3}{*}{ Base flow } & & 2011 & 0.24 & 0.36 & 0.01 & 0.03 \\
\hline & & 2012 & 2.18 & 0.04 & 0.24 & 2.06 \\
\hline & & 2013 & 3.62 & 0.49 & 0.03 & 0.45 \\
\hline \multirow{3}{*}{ Runoff } & & 2011 & 54.08 & 0.08 & 0.30 & 54.90 \\
\hline & & 2012 & 20.03 & 0.98 & 0.96 & 33.45 \\
\hline & & 2013 & 30.70 & 14.68 & 0.14 & 48.37 \\
\hline
\end{tabular}

\section{Total Nitrogen}

Estimated mean annual total nitrogen yields were largest at the Poteau River stations (table 5). Total nitrogen yields ranged from 0.70 to 2.11 ton $\cdot \mathrm{yr}^{-1} \cdot \mathrm{mi}^{-2}$, with the largest annual total nitrogen yield being estimated at the Poteau River at Loving, Okla., station in 2012 and the smallest total nitrogen yield being estimated at the Poteau River near Heavener, Okla., station in 2011 (table 5).

Estimated mean annual total nitrogen yields at base-flow conditions were largest at the Poteau River at Loving, Okla., station (table 5). Estimated mean annual total nitrogen yields at base-flow conditions were smallest at the Fourche Maline near Leflore, Okla., station (table 5). Estimated total nitrogen yields at base-flow conditions at these three stations ranged from 0.018 to 0.381 ton $\cdot \mathrm{yr}^{-1} \cdot \mathrm{mi}^{-2}$. The largest total nitrogen yield during base-flow conditions was estimated at the Poteau River at Loving, Okla., station in 2012, and the smallest yield was estimated at the Fourche Maline station in 2011 during the 3-year study period.

Estimated mean annual total nitrogen yields during runoff conditions were largest at the Poteau River at Loving, Okla., station (table 5). At the Fourche Maline near Leflore, Okla., station, estimated total nitrogen yields during runoff conditions typically were the smallest of the three sampled stations (table 5). Estimated total nitrogen yields during runoff conditions at these stations ranged from 0.63 to 1.73 ton $\cdot \mathrm{yr}^{-1} \cdot \mathrm{mi}^{-2}$. The largest total nitrogen yield during runoff conditions was estimated at the Poteau River at Loving, Okla., station in 2012, and the smallest total nitrogen yield during runoff conditions was estimated at the Poteau River near Heavener, Okla., station in 2011 (table 5). 
Table 8. Estimates of seasonal total nitrogen loads during base-flow and runoff conditions in the Wister Lake Basin, Oklahoma and Arkansas, October 2010 through September 2013.

[Values are loads in tons per season as nitrogen; spring is March through May, summer is June through August, autumn is September through November, and winter is December through February]

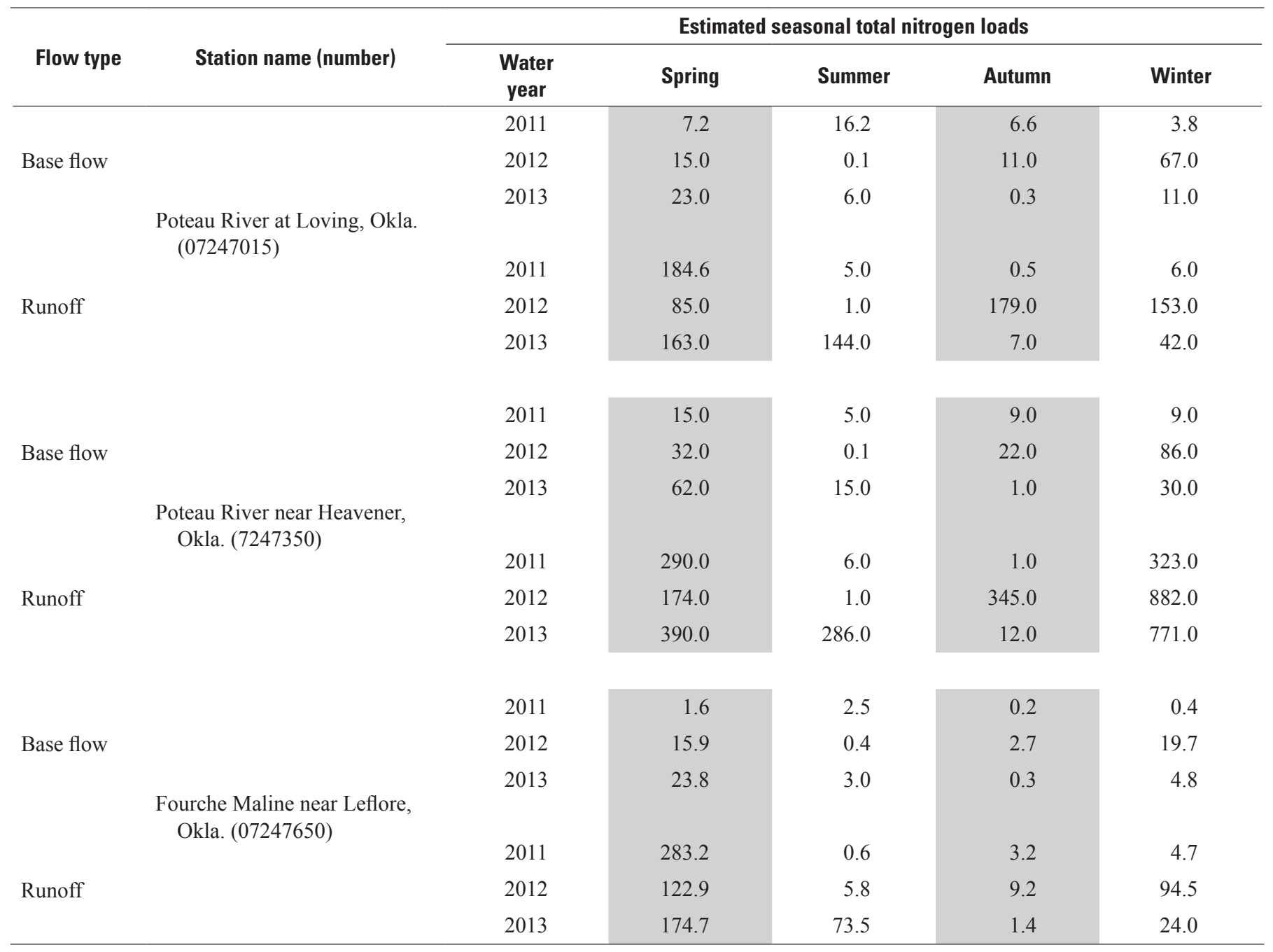


Table 9. Estimates of seasonal suspended sediment loads during base-flow and runoff conditions in the Wister Lake Basin, Oklahoma and Arkansas, October 2010 through September 2013.

[Values are loads in tons per season as sediment; spring is March through May, summer is June through August, autumn is September through November, and winter is December through February]

\begin{tabular}{|c|c|c|c|c|c|c|}
\hline \multirow{2}{*}{$\begin{array}{l}\text { Flow } \\
\text { type }\end{array}$} & \multirow[b]{2}{*}{ Station name (number) } & \multicolumn{5}{|c|}{ Estimated seasonal suspended sediment load } \\
\hline & & $\begin{array}{l}\text { Water } \\
\text { year }\end{array}$ & Spring & Summer & Autumn & Winter \\
\hline \multirow{3}{*}{ Base flow } & & 2011 & 246 & 50 & 122 & 32 \\
\hline & & 2012 & 778 & 1 & 464 & 3,579 \\
\hline & & 2013 & 1,090 & 173 & 4 & 446 \\
\hline \multirow{3}{*}{ Runoff } & & 2011 & 22,846 & 242 & 10 & 238 \\
\hline & & 2012 & 10,038 & 18 & 22,047 & 15,411 \\
\hline & & 2013 & 13,560 & 16,055 & 297 & 3,134 \\
\hline \multirow{3}{*}{ Base flow } & & 2011 & 665 & 198 & 207 & 305 \\
\hline & & 2012 & 1,988 & 3 & 1,037 & 4,244 \\
\hline & & 2013 & 4,083 & 674 & 13 & 1,471 \\
\hline \multirow{3}{*}{ Runoff } & & 2011 & 53,576 & 342 & 36 & 1,251 \\
\hline & & 2012 & 26,986 & 34 & 46,495 & 41,097 \\
\hline & & 2013 & 114,044 & 63,756 & 529 & 7,026 \\
\hline \multirow{3}{*}{ Base flow } & & 2011 & 107 & 125 & 4 & 15 \\
\hline & & 2012 & 1,171 & 14 & 89 & 1,139 \\
\hline & & 2013 & 3,075 & 379 & 9 & 221 \\
\hline \multirow{3}{*}{ Runoff } & & 2011 & 53,728 & 23 & 108 & 208 \\
\hline & & 2012 & 21,641 & 433 & 501 & 10,937 \\
\hline & & 2013 & 25,821 & 11,664 & 48 & 2,005 \\
\hline
\end{tabular}




\section{Suspended Sediment}

Estimated mean annual sediment yields were largest at the Poteau River near Heavener, Okla., station (table 6). The estimated mean annual suspended sediment yield was smallest at the Poteau River at Loving, Okla., station. Suspended sediment yields at the three stations during this period ranged from 89 to 372 ton $\cdot \mathrm{yr}^{-1} \cdot \mathrm{mi}^{-2}$, with the largest yield being estimated at the Poteau River near Heavener, Okla., station in 2013 and the smallest yield being estimated at Poteau River at Loving, Okla., station in 2011 (table 6).

The estimated mean annual suspended sediment yield at base-flow conditions was largest at the Poteau River near Heavener, Okla., station (table 6). Estimated mean annual suspended sediment yields at base-flow conditions were smallest at the Fourche Maline near Leflore, Okla., station. Suspended sediment yields at base-flow conditions ranged from 1 to 18 ton $\cdot \mathrm{yr}^{-1} \cdot \mathrm{mi}^{-2}$ (table 6 ). The largest annual suspended sediment yield at base-flow conditions was estimated at the Poteau River at Loving, Okla., station in 2012, whereas the smallest suspended sediment yield at base-flow conditions was estimated at the Fourche Maline near Leflore, Okla., station in 2011 (table 6).

The estimated mean annual suspended sediment yield at runoff conditions was largest at the Poteau River near Heavener, Okla., station (table 6). Estimated annual suspended sediment yields during runoff conditions ranged from 87 to 360 ton $\cdot \mathrm{yr}^{-1} \cdot \mathrm{mi}^{-2}$ (table 6 ). The largest suspended sediment yield during runoff conditions was estimated at the Poteau River near Heavener, Okla., station in 2013, and the smallest suspended sediment yield at runoff conditions was estimated at the Poteau River at Loving, Okla., station in 2011 (table 6).

\section{Estimated Annual Flow-Weighted Mean Concentrations of Total Phosphorus and Total Nitrogen}

Flow-weighted mean (FWM) concentrations, determined by dividing total annual constituent loads by mean annual streamflow, are useful for investigating trends in constituent concentrations by reducing the effects of wet and dry years on constituent concentrations. The following sections describe annual FWM concentrations of total phosphorus and total nitrogen at three sampled stations in the Wister Lake Basin from October 2011 through September 2013.

\section{Total Phosphorus}

Estimated annual FWM concentrations of total phosphorus were substantially larger than the Oklahoma State Standard for Scenic Rivers of $0.037 \mathrm{mg} / \mathrm{L}$ at the three sampled stations (State of Oklahoma, 2006; table 10). This standard is useful as a point of reference because phosphorus concentrations exceeding that standard may be associated with greater eutrophication in rivers and downstream lakes receiving inflows from rivers. The FWM concentration of total phosphorus was much more stable over the 3-year period at the Poteau River at Loving, Okla., station than at the other two stations (table 10). The FWM concentration of total

Table 10. Estimated annual total phosphorus loads, mean annual streamflows, and flow-weighted mean total phosphorus concentrations at water-quality stations in the Wister Lake Basin, Oklahoma and Arkansas, October 2010 through September 2013.

[ton/yr, tons per year; $\mathrm{ft}^{3} / \mathrm{s}$, cubic feet per second; $\mathrm{mg} / \mathrm{L}$, milligrams per liter]

\begin{tabular}{lcccc}
\hline \multicolumn{1}{c}{ Station name (number) } & $\begin{array}{c}\text { Water } \\
\text { year }\end{array}$ & $\begin{array}{c}\text { Estimated mean } \\
\text { annual total } \\
\text { phosphorus load } \\
\text { (ton/yr as P) }\end{array}$ & $\begin{array}{c}\text { Mean annual } \\
\text { streamflow } \\
\text { (ft } \mathbf{3} \text { ) }\end{array}$ & $\begin{array}{c}\text { Estimated flow-weighted } \\
\text { mean total phosphorus } \\
\text { concentration } \\
\text { (mg/L as P) }\end{array}$ \\
\hline $\begin{array}{l}\text { Poteau River at Loving, Okla. } \\
\text { (07247015) }\end{array}$ & 2011 & 51 & 192.6 & 0.270 \\
& 2012 & 112 & 405.8 & 0.281 \\
& 2013 & 100 & 379.9 & 0.268 \\
Poteau River near Heavener, & 2011 & 79 & 415.0 & 0.194 \\
Okla. (07247350) & 2012 & 164 & 846.7 & 0.197 \\
& 2013 & 225 & 911.0 & 0.251 \\
& & & \\
Fourche Maline near Leflore, & 2011 & 56 & 265.9 & 0.212 \\
Okla. (07247650) & 2012 & 38 & 232.9 & 0.165 \\
\hline
\end{tabular}


phosphorus typically was lower at the Fourche Maline near Leflore, Okla., station than at the Poteau River stations.

\section{Total Nitrogen}

Estimated FWM concentrations of total nitrogen at these three stations were substantially larger than the median flow-weighted concentration $(0.26 \mathrm{mg} / \mathrm{L})$ described for mostly undeveloped basins of the United States by Clark and others (2000) (table 11). Such nitrogen concentrations, along with relatively large phosphorus concentrations in these samples, are likely to be contributing to the eutrophication in Wister Lake. Flow-weighted mean concentrations of total nitrogen did not vary spatially in a consistent manner.

\section{Estimated Annual Total Phosphorus, Total Nitrogen, and Suspended Sediment Loads Discharged into Wister Lake}

Most of the annual total phosphorus, total nitrogen, and suspended sediment loads discharged to Wister Lake can be estimated by adding the loads of the Poteau River near Heavener, Okla., station and the Fourche Maline near Leflore, Okla., station. The estimated loads of total phosphorus, total nitrogen, and suspended sediment at those stations do not represent the entire drainage area for Wister Lake but account for about 84 percent of the drainage basin of the lake.

The Poteau River and the Fourche Maline contributed estimated annual total phosphorus loads of 137 to 278 tons/yr, with 89 to 95 percent of those annual total phosphorus loads being transported to Wister Lake during runoff conditions (table 12). The Poteau River transported several times more total phosphorus to the lake during base-flow and runoff conditions than the Fourche Maline (table 12). The estimated seasonal total phosphorus loads into Wister Lake typically were largest during runoff conditions in the spring at the Poteau River stations and during runoff conditions in the winter at the Fourche Maline near Leflore, Okla., station (table 7).

The Poteau River and the Fourche Maline contributed estimated annual total nitrogen loads of 657 to 1,294 tons/ yr, with 86 to 94 percent of the estimated annual total nitrogen loads being transported to Wister Lake during runoff conditions (table 13). The Poteau River typically transported several times more nitrogen during base-flow and runoff conditions to the lake than the Fourche Maline (table 13). The estimated seasonal total nitrogen loads transported into Wister Lake typically were largest during runoff conditions in the spring at these sampled stations (table 8).

The Poteau River and the Fourche Maline contributed annual estimated suspended sediment loads of 110,919 to 234,637 tons/yr, with 94 to 99 percent of the annual suspended sediment loads being transported to Wister Lake during runoff conditions (table 14). The Poteau River typically transported several times more sediment during base-flow and runoff conditions to the lake than the Fourche Maline (table 14). The estimated seasonal suspended sediment loads into Wister Lake generally were largest during runoff conditions in the spring for all stations (table 9).

Table 11. Estimated annual total nitrogen loads, mean annual streamflows, and flow-weighted mean total nitrogen concentrations at water-quality stations in the Wister Lake Basin, Oklahoma and Arkansas, October 2010 through September 2013.

[ton/yr, tons per year; $\mathrm{ft}^{3} / \mathrm{s}$, cubic feet per second; $\mathrm{mg} / \mathrm{L}$, milligrams per liter]

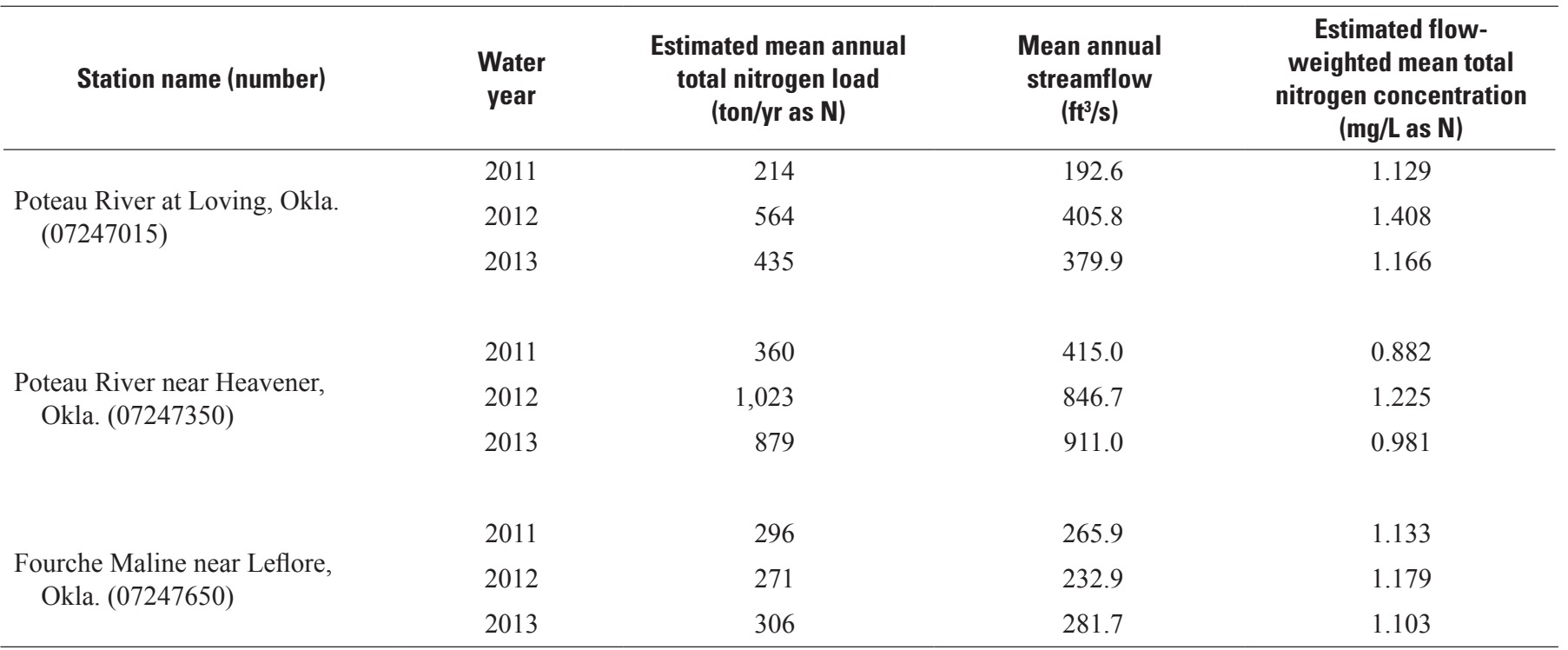


Table 12. Estimated annual total phosphorus loads discharged to Wister Lake, Oklahoma and Arkansas, 0 ctober 2010 through September 2013.

$[\%$, percent; ton $/ \mathrm{yr}$, tons per year $]$

\begin{tabular}{|c|c|c|c|c|}
\hline \multirow{3}{*}{$\begin{array}{c}\text { Flow type } \\
\text { (water year) }\end{array}$} & \multirow{2}{*}{\multicolumn{2}{|c|}{$\begin{array}{c}\begin{array}{c}\text { Discharged to Wister Lake } \\
\text { from } 84 \% \text { of its drainage area }\end{array} \\
\text { Annual phosphorus load }\end{array}$}} & \multirow{3}{*}{$\begin{array}{c}\text { Poteau River near } \\
\text { Heavener, 0kla. } \\
\begin{array}{c}\text { Component of mean annual } \\
\text { phosphorus load } \\
\text { (ton/yr) }\end{array}\end{array}$} & \multirow{3}{*}{$\begin{array}{l}\text { Fourche Maline near } \\
\text { Leflore, Okla. }\end{array}$} \\
\hline & & & & \\
\hline & ton/yr as $P$ & $\%$ & & \\
\hline \multicolumn{5}{|c|}{2011} \\
\hline Runoff $^{3}$ & 130 & 95 & 75 & 55 \\
\hline Total $^{4}$ & 137 & 100 & 81 & 56 \\
\hline \multicolumn{5}{|c|}{2012} \\
\hline Base flow ${ }^{2}$ & 22 & 11 & 17 & 5 \\
\hline Runoff $^{3}$ & 180 & 89 & 147 & 33 \\
\hline \multicolumn{5}{|c|}{2013} \\
\hline Base flow ${ }^{2}$ & 21 & 8 & 16 & 5 \\
\hline Runoff $^{3}$ & 257 & 92 & 209 & 48 \\
\hline Total $^{4}$ & 278 & 100 & 225 & 53 \\
\hline \multicolumn{5}{|c|}{ Average of 3 years, 2011-13 } \\
\hline Base flow $^{2}$ & 17 & & 13 & 4 \\
\hline Runoff $^{3}$ & 189 & & 144 & 45 \\
\hline Total $^{4}$ & 206 & & 157 & 49 \\
\hline
\end{tabular}

${ }^{1}$ Loads to Wister Lake are calculated by adding loads from Poteau River near Heavener, Okla., to loads from Fourche Maline near Leflore, Okla. (table 4). These two stations account for 84 percent of drainage that flows into Wister Lake.

${ }^{2}$ Means of the base-flow loads are calculated from base-flow day data only by using S-LOADEST.

${ }^{3}$ Means of the runoff loads are calculated from runoff day data only by using S-LOADEST.

${ }^{4}$ Differences between total loads and the sum of base flow plus runoff are due to rounding. 
Table 13. Estimated annual total nitrogen loads discharged to Wister Lake, Oklahoma and Arkansas, October 2010 through September 2013.

$[\%$, percent; ton $/ \mathrm{yr}$, tons per year $]$

\begin{tabular}{|c|c|c|c|c|}
\hline \multirow{3}{*}{$\begin{array}{c}\text { Flow type } \\
\text { (water year) }\end{array}$} & \multicolumn{2}{|c|}{$\begin{array}{c}\text { Discharged to Wister Lake from } \\
84 \% \text { of its drainage area }\end{array}$} & \multirow{3}{*}{$\begin{array}{c}\text { Poteau River near Heavener, Okla. } \\
\text { Component of mean } \\
\text { annual nitrogen load } \\
\text { (ton/yr) }\end{array}$} & \multirow{3}{*}{$\begin{array}{l}\text { Fourche Maline near } \\
\text { Leflore, Okla. }\end{array}$} \\
\hline & \multicolumn{2}{|c|}{ Annual nitrogen load' } & & \\
\hline & ton/yr as $\mathrm{N}$ & $\%$ & & \\
\hline \multicolumn{5}{|c|}{2011} \\
\hline Runoff $^{3}$ & 615 & 94 & 323 & 292 \\
\hline Total $^{4}$ & 657 & 100 & 360 & 297 \\
\hline \multicolumn{5}{|c|}{2012} \\
\hline Base flow ${ }^{2}$ & 179 & 14 & 140 & 39 \\
\hline Runoff $^{3}$ & 1,115 & 86 & 883 & 232 \\
\hline Base flow $^{2}$ & 141 & 12 & 109 & 32 \\
\hline Runoff $^{3}$ & 1,044 & 88 & 770 & 274 \\
\hline Total $^{4}$ & 1,185 & 100 & 879 & 306 \\
\hline \multicolumn{5}{|c|}{ Average of 3 years, 2011-13 } \\
\hline Base flow $^{2}$ & 120 & & 95 & 25 \\
\hline Runoff $^{3}$ & 925 & & 659 & 266 \\
\hline Total $^{4}$ & 1,045 & & 754 & 291 \\
\hline
\end{tabular}

${ }^{1}$ Loads to Wister Lake are calculated by adding loads from Poteau River near Heavener, Okla., to loads from Fourche Maline near Leflore, Okla. (table 5). These two stations account for 84 percent of drainage that flows into Wister Lake.

${ }^{2}$ Means of the base-flow loads are calculated from base-flow day data only by using S-LOADEST.

${ }^{3}$ Means of the runoff loads are calculated from runoff day data only by using S-LOADEST.

${ }^{4}$ Differences between total loads and the sum of base flow plus runoff are due to rounding. 
Table 14. Estimated annual total suspended sediment loads discharged to Wister Lake, Oklahoma and Arkansas, 0 ctober 2010 through September 2013.

$[\%$, percent; ton $/ \mathrm{yr}$, tons per year $]$

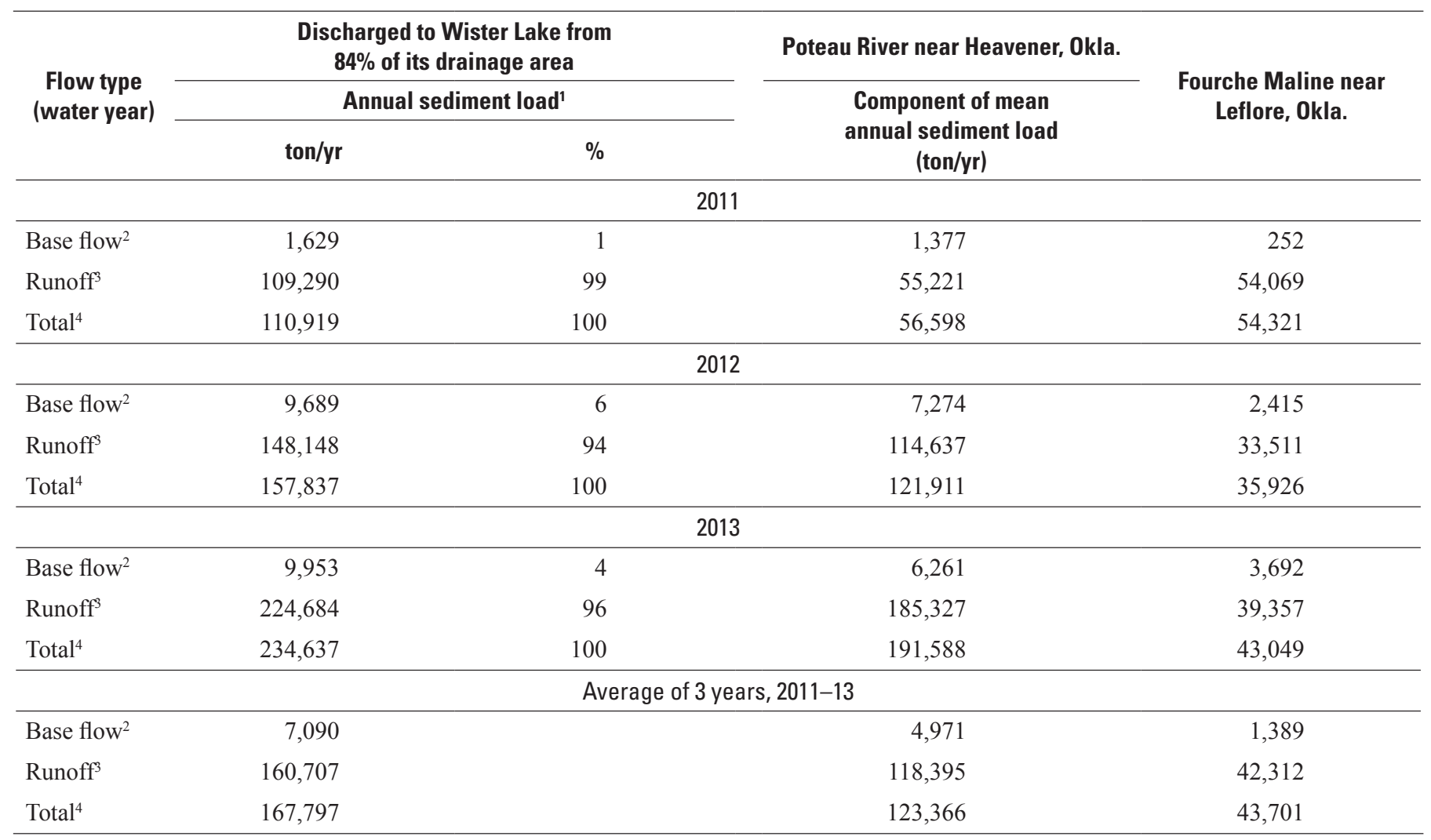

${ }^{1}$ Loads to Wister Lake are calculated by adding loads from Poteau River near Heavener, Okla., to loads from Fourche Maline near Leflore, Okla. (table 6). These two stations account for 84 percent of drainage that flows into Wister Lake.

${ }^{2}$ Means of the base-flow loads are calculated from base-flow day data only by using S-LOADEST.

${ }^{3}$ Means of the runoff loads are calculated from runoff day data only by using S-LOADEST.

${ }^{4}$ Differences between total loads and the sum of base flow plus runoff are due to rounding. 


\section{Summary}

The Poteau Valley Improvement Authority uses Wister Lake in southeastern Oklahoma as a sole source of public water supply. Total phosphorus, total nitrogen, and suspended sediments from agricultural runoff and discharges from wastewater treatment plants and other sources have caused impairment of water quality in the lake. Lake-water quality has degraded, causing water-treatment cost, chemical usage, and sludge production to increase for the Poteau Valley Improvement Authority.

The U.S. Geological Survey, in cooperation with the Poteau Valley Improvement Authority, investigated and summarized concentrations of total phosphorus, total nitrogen, suspended sediment, and bacteria (Escherichia coli and Enterococcus sp.) in surface water flowing to Wister Lake. Estimates of total phosphorus, total nitrogen, and suspended sediment loads and yields, and flow-weighted mean concentrations of total phosphorus and total nitrogen were made for the Wister Lake Basin for a 3-year period, October 2010 through September 2013. Samples collected at fixed time increments during base-flow conditions at the Poteau River at Loving, Okla.; the Poteau River near Heavener, Okla.; and the Fourche Maline near Leflore, Okla., water-quality stations were supplemented with samples collected during runoff conditions to determine water quality over the range of streamflows in the basin. These data also were collected to estimate annual constituent loads by using regression models.

Total phosphorus, total nitrogen, and suspended sediment concentrations were significantly larger in water samples collected during runoff conditions than in samples collected during base-flow conditions at the Poteau River stations. Bacteria (Escherichia coli and Enterococcus sp.) concentrations also were significantly larger in water samples collected during runoff conditions than in water samples collected during base-flow conditions from 2011 to 2013 at the three sampled stations.

Concentrations of total phosphorus, total nitrogen, suspended sediment, and bacteria (Escherichia coli and Enterococcus sp.) in water samples collected during baseflow conditions generally were larger at the Fourche Maline station than at the Poteau River stations. Total phosphorus, total nitrogen, and suspended sediment concentrations in water samples collected during runoff conditions were larger at the Poteau River stations than at the Fourche Maline near Leflore, Okla., station.

Estimated annual total phosphorus and total nitrogen loads generally were larger at the Poteau River stations than at the Fourche Maline near Leflore, Okla., station. Estimated annual suspended sediment loads were largest at the Poteau River near Heavener, Okla., station and generally were smallest at the Poteau River at Loving, Okla., station. Estimated annual total phosphorus, total nitrogen, and suspended sediment loads at the Poteau River stations at base-flow conditions generally were larger than at the Fourche Maline near Leflore, Okla., station. The estimated annual loads of total phosphorus, total nitrogen, and suspended sediment in the Poteau River stations during runoff conditions ranged from 82 to 98 percent of the total annual loads of those constituents. The estimated annual loads of total phosphorus, total nitrogen, and suspended sediment in the Fourche Maline during runoff conditions ranged from 86 to nearly 100 percent of the total annual loads.

Estimated seasonal total phosphorus loads generally were smallest during base-flow and runoff conditions in autumn. Estimated seasonal total phosphorus loads during base-flow conditions generally were largest in winter and during runoff conditions generally were largest in the spring. Estimated seasonal total nitrogen loads generally were smallest in autumn during base-flow conditions and largest in winter during runoff conditions. Estimated seasonal suspended sediment loads generally were smallest during base-flow conditions in the summer and during runoff conditions in the autumn. The largest estimated seasonal suspended sediment loads typically were in the spring during runoff conditions.

Estimated mean annual total phosphorus yields were largest at the Poteau River at Loving, Okla., station. The estimated mean total phosphorus yields were largest during base-flow at the Poteau River at Loving, Okla., station. Estimated mean annual total nitrogen yields were largest at the Poteau River stations. The estimated mean total nitrogen yields during base-flow and runoff conditions were largest at the Poteau River at Loving, Okla., station. Estimated mean annual, base-flow, and runoff yields of suspended sediment were largest at the Poteau River near Heavener, Okla., station.

Flow-weighted mean total phosphorus concentrations at all three stations from 2011 to 2013 were several times larger than Oklahoma State Standard for Scenic Rivers (0.037 milligrams per liter), with the largest flow-weighted phosphorus concentrations typically being measured at the Poteau River at Loving, Okla., station. Flow-weighted mean concentrations indicated that total phosphorus inputs from the Poteau River Basin in the Wister Lake Basin were larger than from the Fourche Maline Basin. Flow-weighted mean concentrations of total nitrogen did not vary spatially in a consistent manner. Flow-weighted mean total nitrogen concentrations did not vary substantially between the Poteau River stations and the Fourche Maline near Leflore, Okla., station.

The Poteau River and the Fourche Maline contributed estimated annual total phosphorus loads of 137 to 278 tons per year to Wister Lake. Between 89 and 95 percent of the annual total phosphorus loads were transported to Wister Lake during runoff conditions. The Poteau River typically transported several times larger total phosphorus loads during base-flow conditions and runoff conditions than the Fourche Maline. The Poteau River and the Fourche Maline contributed estimated 
annual total nitrogen loads of 657 to 1,294 tons per year, with 86 to 94 percent of the annual total nitrogen loads being transported to Wister Lake during runoff conditions. Several times larger total nitrogen loads typically were delivered to the lake during base-flow and runoff conditions from the Poteau River than the Fourche Maline. The Poteau River and the Fourche Maline contributed estimated annual total suspended sediment loads of 110,919 to 234,637 tons per year, with 94 to 99 percent of the annual suspended sediment loads being transported to Wister Lake during runoff conditions. Several times more suspended sediment loads typically were transported to the lake by the Poteau River than the Fourche Maline. Most of the total phosphorus, total nitrogen, and suspended sediment were discharged to Wister Lake during runoff conditions in the spring.

\section{Selected References}

Andrews, W.J., Becker, M.F., Smith, S.J., and Tortorelli, R.L., 2009, Summary of surface-water quality data from the Illinois River Basin in North Oklahoma, 1970-2007: U.S. Geological Survey Scientific Investigations Report 20095182, 39 p. (Revised April 2010)

Busteed, P.R., Storm, D.E., White, M.J., and Stoodley, S.H., 2009, Using SWAT to target critical source suspended sediment and phoshporus areas in the Wister Lake Basin, USA: American Journal of Environmental Sciences, v. 5, no. 2 , p. 156-163.

Clark, G.M., Mueller, D.K., and Mast, M.A., 2000, Nutrient concentrations and yields in undeveloped stream basins of the United States: Journal of the American Water Resources Association, v. 36, no. 4, p. 849-860.

Cohn, T.A., DeLong, L.L., Gilroy, E.J., Hirsch, R.M., and Wells, D.K., 1989, Estimating constituent loads: Water Resources Research, v. 25, no. 5, p. 937-942.

Crawford, C.G., 1991, Estimation of suspended-suspended sediment rating curves and suspended-suspended sediment loads: Journal of Hydrology, v. 129, no. 1, p. 331-348.

Dempster, A.P., Laird, N.M., and Rubin, D.B., 1977, Maximum likelihood from incomplete data via the EM algorithm: Journal of the Royal Statistical Society, series B, v. 39 , no. 1 , p. 1-38.
Edwards, T.K., and Glysson, G.D., 1999, Field methods for measurements of fluvial suspended sediment: U.S. Geological Survey Techniques of Water-Resources Investigations, book 3, chap C2, $89 \mathrm{p}$.

Esralew, R.A., Andrews, W.J., Allen, M.L.O., and Becker, C.J., 2011, Comparison of load estimation techniques and trend analysis for nitrogen, phosphorus, and suspended sediment in the Eucha-Spavinaw Basin, northwestern Arkansas and northeastern Oklahoma, 2002-10: U.S. Geological Survey Scientific Investigations Report 2011-5127, 58 p.

Harwell, G.R., and Mobley, C.A., 2009, Occurrence and distribution of fecal indicator bacteria, and physical and chemical indicators of water quality in streams receiving discharge from Dallas/Fort Worth International Airport Vicinity, north-central Texas, 2008: U.S. Geological Survey Scientific Investigations Report 2009-5103, 44 p.

Helsel, D.R., and Hirsch, R.M., 1992, Statistical methods in water resources: Amsterdam, Netherlands, Elsevier, 522 p.

Hession, W.C., Storm, D.E., Haan, C.T., Burks, S.L., and Matlock, M.D., 1996, A watershed-level ecological risk assessment methodology: Journal of the American Water Resources Association, v. 32, p. 1039-1054.

IDEXX Laboratories, 2009, Water microbiology/Colilert/ Document library/Colilert procedure: IDEXX Laboratories, accessed December 15, 2013, at http://www.idexx.com/ water/refs/0612999_c.pdf.

Insightful Corporation, 2005, S-Plus 7.0 for Windows professional developer release edition with release 3.0 of the U.S. Geological Survey S-Plus Library: Insightful Corporation, Seattle, Washington.

Institute of Hydrology, 1980a, Low flow studies: Wallington, Oxon, United Kingdom, Institute of Hydrology Report, no. $1,21 \mathrm{p}$.

Institute of Hydrology, 1980b, Low flow studies: Wallington, Oxon, United Kingdom, Institute of Hydrology Report, no. 3, p. 12-19.

Langbein, W.B., and Iseri, K.T., 1960, General introductions and hydrologic definitions-Manual of Hydrology — Part I, general surface-water techniques: U.S. Geological Survey Water-Supply Paper 1541-A, 29 p. 
Mott, D.N., and Steele, K.F., 1991, Effects of pasture runoff on water chemistry, Buffalo National River, USA, in Peters, N.E., and Walling, D.E., eds., Suspended sediment and stream water quality in a changing environment-Trends and explanation, 20th, Vienna, Austria, 1991, Proceedings: Vienna, Austria, 20th General Assembly of the International Union of Geodesy and Geophysics, p. 229-238.

Multi-Resolution Land Characteristics Consortium, 2013, National land cover database 2006: Multi-Resolution Land Characteristics Consortium, accessed December 15, 2013, at http://www.mrlc.gov/nlcd2006.php.

Oklahoma Conservation Commission, 2001a, Watershed restoration action strategy (WRAS) for the Poteau River/Wister Lake watershed: Oklahoma Conservation Commission, accessed December 15, 2013, at http://www. ok.gov/triton/search.php?cref=http $\% 3 \mathrm{~A} \% 2 \mathrm{~F} \% 2 \mathrm{Fwww}$. ok.gov $\% 2$ Ftriton $\% 2$ Fcse_search_xml.php?site=http://www. ok.gov/conservation/*\&sitesearch=http://www.ok.gov/ conservation $/ \& \mathrm{q}=1 \mathrm{ake} \% 20 \mathrm{wister} \% 20 \mathrm{basin} \&$ as_epq $=\&$ as oq $=\&$ as_eq $=\&$ as_occt $=$ any $\&$ sort $=\&$ num $=10 \&$ cof $=$ FORID $\% 3 \mathrm{~A} 9 \% 3 \mathrm{BNB} \% 3 \mathrm{~A} 1 \# 947$.

Oklahoma Conservation Commision, 2001b, Poteau River comprehensive watershed management program: Oklahoma Conservation Commission, accessed December 15, 2013, at http://www.ok.gov/triton/search. php?cref $=$ http $\% 3 \mathrm{~A} \% 2 \mathrm{~F} \% 2 \mathrm{Fwww}$. ok.gov $\% 2 \mathrm{Ftriton} \% 2 \mathrm{Fcse}$ search_xml.php?site=http://www.ok.gov/conservation/*\& sitesearch=http://www.ok.gov/conservation/\&q=lake $\% 20$ wister\%20basin\&as_epq $=\&$ as_oq $=\&$ as_eq $=\&$ as_occt $=$ any \&sort=\&num=10\&cof=FORID\%3A9\%3BNB\%3A1\#947.

Oklahoma Department of Environmental Quality, 2008, Water quality in Oklahoma, 2008, integrated report: Oklahoma Department of Environmental Quality, accessed November 20, 2013, at http://www.deq.state.ok.us/ WQDnew/305b_303d/2008_integrated_report_entire_ document.pdf.

Oklahoma Department of Environmental Quality, 2014, 2014 Bacterial and turbidity total maximum daily loads for Oklahoma Streams in the Lower Arkansas river area (Draft): Oklahoma Department of Environmental Quality, $151 \mathrm{p}$.

Petersen, T.M., Rifai, H.S., Suarez, M.P., and Stein, A.R., 2005, Bacteria loads from point and nonpoint sources in an urban watershed: Journal of Environmental Engineering, v. 131, no. 10, p. 1414-1425.
Poteau Valley Improvement Authority, 2009, Restoring Wister Lake-PVIA's strategic plan to improve water quality and enhance the lake ecosystem: Poteau Valley Improvement Authority, accessed February 26, 2013, at http://www.pvia. org/wp-content/uploads/2009/11/0.2.ExecSum.10-26-09. pdf.

Pritt, J.W., and Raese, J.W., 1995, Quality assurance/quality control manual—National Water Quality Laboratory: U.S. Geological Survey Open-File Report 94-26, 15 p.

Rantz, S.E., and others, 1982, Measurement and computation of streamflow-Volume 2, computation of discharge: U.S. Geological Survey Water-Supply Paper 2175, v. 2, 285 p.

Ries, K.G., and Friesz, P. J., 2000, Methods for estimating low-flow statistics for Massachusetts streams: U.S. Geological Survey Water-Resources Investigations Report 00-4135, $81 \mathrm{p}$.

Risley, J.C., Stonewall, Adam, and Haluska, T.L., 2008, Estimating flow-duration and low-flow frequency statistics for unregulated streams in Oregon: U.S. Geological Survey Scientific Investigations Report 2008-5126, 22 p.

Runkel, R.L., Crawford, C.G., and Cohn, T.A., 2004, Load estimator (LOADEST) - A FORTRAN program for estimating constituent loads in streams and rivers: U.S. Geological Survey Techniques and Methods, book 4, chapter 5, accessed January 4, 2014, at http://pubs.usgs.gov/ $\mathrm{tm} / 2004 / \mathrm{tm} 4 \mathrm{~A} 5$.

State of Oklahoma, 2006, Title 785, Oklahoma Water Resources Board, chapter 46, implementation of Oklahoma's water quality standards, unofficial 785-46: Oklahoma Water Resources Board, 44 p., accessed March 5, 2014, at http://www.owrb.ok.gov/util/rules/pdf_rul/Chap46. pdf.

Storm, D.E., White, Michael, Smolen, M.D., and Zang, Hailin, 2001, Modeling total phosphorus loading for the Lake Eucha Basin: Stillwater, Okla., Oklahoma State University, Biosystems and Agriculture Engineering Department, 14 .

Tortorelli, R.L., 2008, Nutrient concentrations, loads, and yields in the Eucha-Spavinaw Basin, Arkansas and Oklahoma, 2002-2006: U.S. Geological Survey Scientific Investigations Report 2008-5174, 56 p.

Tortorelli, R.L., 2009, Water use in Oklahoma 1950-2005: U.S. Geological Survey Scientific Investigations Report 2009-5212, 49 p. 
U.S. Census Bureau, 2012, County population estimatesU.S. Census Bureau population estimates: U.S. Census Bureau, accessed December 15, 2013, at http://www.census. gov/popest/data/counties/totals/2012/CO-EST2012-01.html.

U.S. Department of Agriculture, 2007, The census of agriculture - 2007 Census report: U.S. Department of Agriculture, accessed December 15, 2013, at http://www. agcensus.usda.gov/Publications/2007/Full_Report/Census_ by_State/.

U.S. Environmental Protection Agency, 2009, National water quality inventory-Report to Congress, 2004 reporting cycle: U.S. Environmental Protection Agency, Office of Water, 841-R-08-001, 37 p.

U.S. Environmental Protection Agency, 2013, Overview of impaired waters and total maximum daily loads program: U.S. Environmental Protection Agency, accessed May 19, 2014, at http://water.epa.gov/lawsregs/lawsguidance/cwa/ tmdl/overviewoftmdl.cfm.

U.S. Geological Survey, 1999, The quality of our Nation's waters-Nutrients and pesticides: U.S. Geological Survey Circular 1225, 82 p.
U.S. Geological Survey, 2006, National field manual for the collection of water-quality data, collections of water sample: U.S. Geological Survey Techniques of WaterResources Investigations Reports, book 9, chap. A4, 166 p., accessed November 20, 2013, at http://water.usgs.gov/owq/ FieldManual/chapter4/pdf/Chap4_v2.pdf.

U.S. Geological Survey, 2013, USGS water data for Oklahoma: U.S. Geological Survey, accessed December 15, 2013, at http://water.usgs.gov/ok/nwis.

Wahl, K.L., and Tortorelli, R.L., 1997, Changes in flow in the Beaver-North Canadian River Basin upstream from Canton Lake, western Oklahoma: U.S. Geological Survey WaterResources Investigations Report 96-4304, 58 p.

Wahl, K.L., and Wahl, T.L., 1988, Effects of regional groundwater declines on streamflows in the Oklahoma Panhandle-Symposium on water-use data for water resources management: Tucson, Arizona, American Water Resources Association, p. 239-249.

Wilson, Lee, 1972, Seasonal suspended sediment yield patterns of U.S. rivers: Water Resources Research, v. 8, no. 6, p. 1470-1479, doi: 10.1029/WR008i006p01470. 
Appendixes 1-3 

Appendix 1. Instantaneous streamflows, total phosphorus concentrations, total nitrogen concentrations, suspended sediment concentrations, bacteria concentrations, and flow category for Poteau River at Loving, Oklahoma, from 2010 to 2013.

$\left[\mathrm{ft}^{3} / \mathrm{s}\right.$, cubic feet per second; $\mathrm{mg} / \mathrm{L}$, milligrams per liter; $\mathrm{mL}$, milliliter; <, less than; >, greater than. All water-quality data available at http://water.usgs.gov/ok/nwis]

\begin{tabular}{|c|c|c|c|c|c|c|c|c|}
\hline Date & $\begin{array}{c}\text { Sample } \\
\text { time }\end{array}$ & $\begin{array}{c}\text { Streamflow } \\
\left(\mathrm{ft}^{3} / \mathbf{s}\right)\end{array}$ & $\begin{array}{c}\text { Total } \\
\text { phosphorus } \\
\text { concentration } \\
\text { (mg/L as } \mathrm{P} \text { ) }\end{array}$ & $\begin{array}{c}\text { Total } \\
\text { nitrogen } \\
\text { concentration } \\
\text { (mg/L as } \mathrm{N} \text { ) }\end{array}$ & $\begin{array}{c}\text { Enterococcus sp. } \\
\text { concentration } \\
\text { (colonies per } \\
100 \mathrm{~mL} \text { ) }\end{array}$ & $\begin{array}{l}\text { Escherichia } \\
\text { coli } \\
\text { (colonies per } \\
100 \mathrm{~mL} \text { ) }\end{array}$ & $\begin{array}{l}\text { Suspended } \\
\text { sediment } \\
\text { (mg/L) }\end{array}$ & $\begin{array}{l}\text { Flow } \\
\text { type }\end{array}$ \\
\hline $10 / 19 / 2010$ & 1600 & 61 & 0.152 & 1.1 & & & 9 & Base flow \\
\hline $12 / 9 / 2010$ & 1600 & 7 & 0.047 & $<0.50$ & & & 5 & Base flow \\
\hline 3/7/2011 & 1455 & 17 & 0.057 & 0.85 & & & 12 & Base flow \\
\hline $4 / 11 / 2011$ & 1530 & 32 & 0.07 & 0.59 & 370 & 20 & 28 & Base flow \\
\hline $4 / 15 / 2011$ & 1330 & 1,400 & 0.391 & 1.7 & $>4,800$ & 14,000 & 315 & Runoff \\
\hline $4 / 20 / 2011$ & 1430 & 73 & 0.097 & 0.91 & 460 & 40 & 22 & Base flow \\
\hline $4 / 26 / 2011$ & 1200 & 10,400 & 0.187 & 1 & $>4,800$ & 3,100 & 88 & Runoff \\
\hline $5 / 2 / 2011$ & 1330 & 7,070 & 0.461 & 1.4 & $>4,800$ & 9,600 & 66 & Runoff \\
\hline $5 / 23 / 2011$ & 1430 & 323 & 0.302 & 1.2 & 220 & 200 & 50 & Runoff \\
\hline 6/7/2011 & 1200 & 30 & 0.062 & $<0.50$ & 1,300 & 63 & 14 & Base flow \\
\hline $8 / 16 / 2011$ & 900 & 12 & 0.068 & 0.53 & 1,500 & 170 & & Runoff \\
\hline $10 / 4 / 2011$ & 930 & 0.67 & 0.043 & 0.5 & 96 & 63 & 3 & Base flow \\
\hline $11 / 9 / 2011$ & 1330 & 1,340 & 0.401 & 2.4 & $>4,800$ & 6,100 & 197 & Runoff \\
\hline $11 / 22 / 2011$ & 1430 & 17,200 & 0.428 & 1.6 & $>4,800$ & 8,400 & 554 & Runoff \\
\hline $12 / 5 / 2011$ & 1345 & 5,050 & 0.236 & 1.4 & $>4,800$ & 1,800 & 74 & Runoff \\
\hline $12 / 8 / 2011$ & 915 & 1,160 & 0.076 & 1 & 120 & 310 & 14 & Base flow \\
\hline 2/7/2012 & 930 & 745 & 0.06 & 0.7 & 40 & 120 & & Runoff \\
\hline $3 / 12 / 2012$ & 1130 & 3,500 & 0.317 & 0.93 & $>4,800$ & 5,000 & 114 & Runoff \\
\hline $3 / 21 / 2012$ & 1145 & 6,490 & 0.258 & 0.96 & $>4,800$ & 3,700 & 94 & Runoff \\
\hline $4 / 10 / 2012$ & 930 & 64 & 0.047 & 0.51 & 46 & 63 & 11 & Base flow \\
\hline $6 / 12 / 2012$ & 1530 & 1.5 & 0.055 & 0.63 & $>4,800$ & $<10$ & 10 & Base flow \\
\hline $6 / 13 / 2012$ & 1030 & 1.9 & 0.051 & 0.54 & $>4,800$ & 31 & 7 & Base flow \\
\hline $8 / 16 / 2012$ & 830 & 0.82 & 0.052 & 0.66 & 260 & 52 & 5 & Base flow \\
\hline $10 / 17 / 2012$ & 1100 & 77 & 0.204 & 1.7 & 1,200 & 340 & 44 & Runoff \\
\hline $10 / 24 / 2012$ & 1200 & 7.9 & 0.113 & 1.4 & 69 & 160 & 10 & Runoff \\
\hline $12 / 18 / 2012$ & 930 & 3.1 & 0.054 & 0.65 & 56 & 130 & 3 & Base flow \\
\hline $1 / 14 / 2013$ & 1000 & 1,010 & 0.309 & 1.7 & $>4,800$ & 3,100 & 86 & Runoff \\
\hline $1 / 31 / 2013$ & 1100 & 777 & 0.299 & 1.6 & $>4,800$ & 8,700 & 60 & Runoff \\
\hline 3/7/2013 & 1000 & 122 & 0.052 & $<0.50$ & 13 & $<10$ & 11 & Base flow \\
\hline $3 / 11 / 2013$ & 1400 & 1,880 & 0.229 & 1.1 & 1,800 & 2,100 & 73 & Runoff \\
\hline $4 / 3 / 2013$ & 1315 & 7,110 & 0.413 & 1.1 & $>4800$ & 9,100 & 234 & Runoff \\
\hline 4/24/2013 & 1530 & 149 & 0.051 & 0.52 & 350 & 63 & 12 & Base flow \\
\hline $5 / 22 / 2013$ & 1045 & 2,620 & 0.438 & 1.8 & $>4,800$ & 6,900 & 134 & Runoff \\
\hline $6 / 26 / 2013$ & 1330 & 59 & 0.083 & 0.72 & & & 15 & Base flow \\
\hline $8 / 14 / 2013$ & 1200 & 1,410 & 0.241 & 1.2 & 4,000 & 860 & 82 & Runoff \\
\hline $8 / 28 / 2013$ & 900 & 36 & 0.057 & $<0.50$ & 37 & 41 & 15 & Base flow \\
\hline
\end{tabular}


Appendix 2. Instantaneous streamflows, total phosphorus concentrations, total nitrogen concentrations, suspended sediment concentrations, bacteria concentrations, and flow category for Poteau River near Heavener Oklahoma from 2010 to 2013.

$\left[\mathrm{ft}^{3} / \mathrm{s}\right.$, cubic feet per second; $\mathrm{mg} / \mathrm{L}$, milligrams per liter; $\mathrm{mL}$, milliliter; <, less than; >, greater than. All water-quality data available at http://water.usgs.gov/ok/nwis]

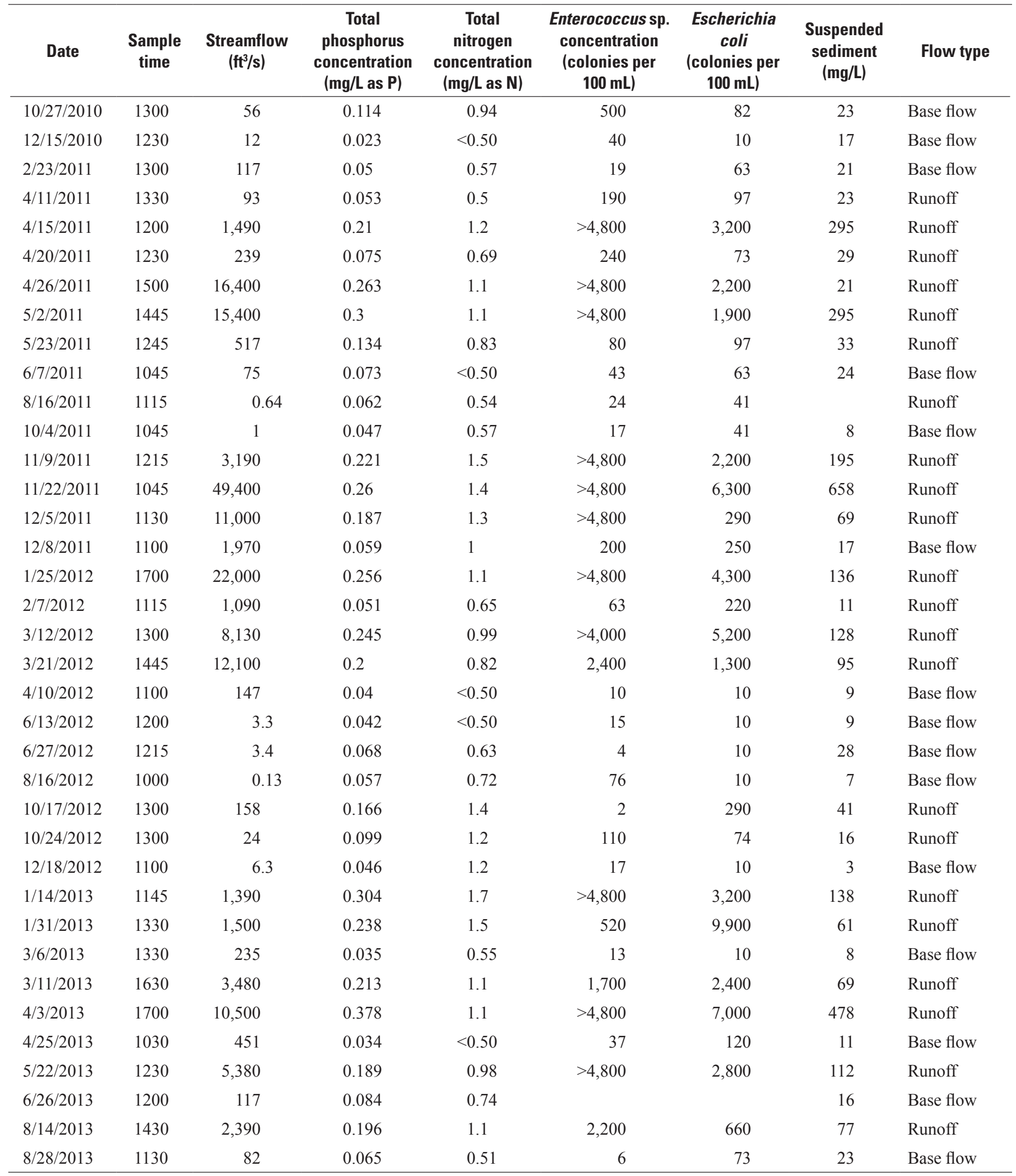


Appendix 3. Instantaneous streamflows, total phosphorus concentrations, total nitrogen concentrations, suspended sediment concentrations, bacteria concentrations, and flow category for Fourche Maline near Leflore, Oklahoma, from 2010 to 2013.

$\left[\mathrm{ft}^{3} / \mathrm{s}\right.$, cubic feet per second; $\mathrm{mg} / \mathrm{L}$, milligrams per liter; $\mathrm{mL}$, milliliter; <, less than; >, greater than. All water-quality data available at http://water.usgs.gov/ok/nwis]

\begin{tabular}{|c|c|c|c|c|c|c|c|c|}
\hline Date & $\begin{array}{l}\text { Sam- } \\
\text { ple } \\
\text { time }\end{array}$ & $\begin{array}{c}\text { Streamflow } \\
\left(\mathrm{ft}^{3} / \mathrm{s}\right)\end{array}$ & $\begin{array}{c}\text { Total } \\
\text { phosphorus } \\
\text { concentration } \\
\text { (mg/L as } \mathrm{P} \text { ) }\end{array}$ & $\begin{array}{c}\text { Total } \\
\text { nitrogen } \\
\text { concentration } \\
\text { (mg/L as N) }\end{array}$ & $\begin{array}{l}\text { Enterococcus sp. } \\
\text { concentration } \\
\text { (colonies per } \\
100 \mathrm{~mL} \text { ) }\end{array}$ & $\begin{array}{l}\text { Escherichia } \\
\text { coli } \\
\text { (colonies per } \\
100 \mathrm{~mL} \text { ) }\end{array}$ & $\begin{array}{l}\text { Suspended } \\
\text { sediment } \\
\text { (mg/L) }\end{array}$ & Flow type \\
\hline $10 / 27 / 2010$ & 945 & 0.01 & 0.034 & 0.55 & 180 & $<10$ & 23 & Runoff \\
\hline $12 / 15 / 2010$ & 1030 & 0.17 & 0.051 & 0.56 & 100 & 20 & 24 & Runoff \\
\hline $2 / 23 / 2011$ & 1030 & 12 & 0.045 & 0.58 & 27 & 160 & 28 & Runoff \\
\hline 4/11/2011 & 1130 & 44 & 0.069 & 0.52 & 820 & 490 & 71 & Base flow \\
\hline $4 / 15 / 2011$ & 1030 & 2,230 & 0.33 & 1.8 & $>4,800$ & 7,500 & 357 & Runoff \\
\hline $4 / 20 / 2011$ & 930 & 167 & 0.075 & 0.86 & 980 & 110 & 40 & Runoff \\
\hline $4 / 26 / 2011$ & 1730 & 5,690 & 0.287 & 1 & $>4,800$ & 2,100 & 93 & Runoff \\
\hline $5 / 2 / 2011$ & 1400 & 5,310 & 0.14 & 0.89 & $>4,800$ & 2,400 & 67 & Runoff \\
\hline $5 / 23 / 2011$ & 1000 & 1,450 & 0.172 & 1 & 1,800 & 1,400 & 102 & Runoff \\
\hline 6/7/2011 & 830 & 37 & 0.09 & 0.64 & 87 & 41 & 23 & Base flow \\
\hline 8/16/2011 & 1300 & 0.34 & 0.039 & $<0.50$ & 60 & $<10$ & & Runoff \\
\hline $11 / 9 / 2011$ & 945 & 35 & 0.056 & & 1,700 & 660 & 31 & Runoff \\
\hline $11 / 22 / 2011$ & 800 & 2,590 & 0.248 & 2.3 & $>4,800$ & 24,000 & 281 & Runoff \\
\hline $12 / 5 / 2011$ & 930 & 948 & 0.137 & 1.7 & 410 & 1,300 & 104 & Runoff \\
\hline $12 / 8 / 2011$ & 1400 & 221 & 0.04 & 1.7 & 170 & 84 & 26 & Base flow \\
\hline $1 / 25 / 2012$ & 1400 & 6,540 & 0.336 & 1.5 & 3,500 & 4,000 & 168 & Runoff \\
\hline 2/7/2012 & 1300 & 541 & 0.071 & 1.1 & 120 & 350 & 45 & Base flow \\
\hline $3 / 12 / 2012$ & 1000 & 8,130 & 0.057 & 0.65 & 340 & 870 & & Runoff \\
\hline $3 / 21 / 2012$ & 900 & 5,480 & 0.182 & 1.1 & 4,000 & 10,000 & 78 & Runoff \\
\hline $4 / 10 / 2012$ & 1330 & 147 & 0.079 & 0.78 & 92 & 98 & 28 & Base flow \\
\hline $6 / 13 / 2012$ & 1400 & 15 & 0.058 & 0.51 & 150 & 30 & 18 & Runoff \\
\hline $6 / 27 / 2012$ & 1030 & 3.7 & 0.096 & 0.71 & 54 & $<10$ & 48 & Base flow \\
\hline $8 / 16 / 2012$ & 1200 & 0.01 & 0.075 & 0.94 & 54 & $<10$ & 15 & Base flow \\
\hline $10 / 17 / 2012$ & 1500 & 28 & 0.143 & 0.92 & 610 & 340 & 69 & Runoff \\
\hline $10 / 24 / 2012$ & 1015 & 0.27 & 0.063 & 0.64 & 130 & $<10$ & 18 & Runoff \\
\hline $1 / 14 / 2013$ & 1430 & 13 & 0.066 & 0.55 & 88 & 74 & 10 & Runoff \\
\hline $1 / 31 / 2013$ & 1530 & 246 & 0.146 & 1.1 & 2,400 & 410 & 80 & Runoff \\
\hline 3/6/2013 & 1300 & 61 & 0.062 & 0.85 & 37 & 31 & 23 & Base flow \\
\hline $3 / 11 / 2013$ & 1130 & 1,950 & 0.353 & 1.6 & 2,800 & 2,800 & 514 & Runoff \\
\hline 4/3/2013 & 1030 & 3,500 & 0.294 & 1.2 & 4,000 & 8,600 & & Runoff \\
\hline $4 / 25 / 2013$ & 1230 & 142 & 0.059 & 0.62 & 61 & 63 & 39 & Base flow \\
\hline $5 / 21 / 2013$ & 1430 & 6,230 & 0.717 & 2.5 & $>4,800$ & 6,400 & 820 & Runoff \\
\hline $5 / 22 / 2013$ & 1330 & 3,020 & 0.204 & 1.1 & $>4,800$ & 3,100 & 157 & Runoff \\
\hline $6 / 26 / 2013$ & 1530 & 20 & 0.058 & 0.6 & & & 9 & Base flow \\
\hline $8 / 28 / 2013$ & 1345 & 5 & 0.061 & 0.53 & 32 & 20 & 14 & Base flow \\
\hline
\end{tabular}


Publishing support provided by Lafayette and Tacoma Publishing Service Centers 
